\title{
Review
}

Siti Nurul Akmal Yusof*, Nor Azwadi Che Sidik*, Yutaka Asako, Wan Mohd. Arif Aziz Japar, Saiful Bahri Mohamed, and Nura Mu’az Muhammad

\section{A comprehensive review of the influences of nanoparticles as a fuel additive in an internal combustion engine (ICE)}

https://doi.org/10.1515/ntrev-2020-0104

received August 17, 2020; accepted December 6, 2020
* Corresponding author: Siti Nurul Akmal Yusof, Department of Mechanical Precision Engineering, Malaysia-Japan International Institute of Technology, Universiti Technologi Malaysia, Jalan Sultan Yahya Petra, 54100 Kuala Lumpur, Malaysia,

e-mail: sitinurulakmal@utm.my

* Corresponding author: Nor Azwadi Che Sidik, Department of Mechanical Precision Engineering, Malaysia-Japan International Institute of Technology, Universiti Technologi Malaysia, Jalan Sultan Yahya Petra, 54100 Kuala Lumpur, Malaysia,

e-mail: azwadi@utm.my

Yutaka Asako, Wan Mohd. Arif Aziz Japar, Nura Mu'az Muhammad: Department of Mechanical Precision Engineering, Malaysia-Japan International Institute of Technology, Universiti Technologi Malaysia, Jalan Sultan Yahya Petra, 54100 Kuala Lumpur, Malaysia Saiful Bahri Mohamed: School of Manufacturing Technology, Faculty of Innovative Design and Technology, Universiti Sultan Zainal Abidin, 21300 Terengganu, Malaysia
Keywords: nanoparticles, ICE, diesel/biodiesel, fuel properties, combustion efficiency, emission control

\section{Introduction}

Global warming is expected to be the biggest challenge of the twenty-first century. The average temperature of the Earth increased by about $0.4-0.8^{\circ} \mathrm{C}$ in the past 10 decades [1,2]. Recently, the scientists from the Intergovernmental Panel on Climate Change have estimated that the average global temperatures will continue to rise by $1.4-5.8^{\circ} \mathrm{C}$ by the year 2100 [3]. Carbon dioxide $\left(\mathrm{CO}_{2}\right)$, water vapour, methane $\left(\mathrm{CH}_{4}\right)$, sulphur dioxide $\left(\mathrm{SO}_{2}\right)$, chlorofluorocarbon, and nitrogen dioxide $\left(\mathrm{NO}_{\mathrm{x}}\right)$ are well known as the major contributors to the greenhouse effects.

Recently, many researchers have focused on developing a wide spectrum of renewable energies including oxygenated fuels, biofuel ( $n$-butanol), fuel cell, and solar technologies to reduce the consumption of fossil fuels and control the emission of greenhouse gases (GHGs) to the atmosphere [4-7]. One of the most effective methods in controlling the emission of GHGs is to reduce the emission of $\mathrm{CO}_{2}$ by reducing fossil fuel consumption [8-11]. $\mathrm{CO}_{2}$ is directly related to the carbon content of the fuel and the amount of fuel consumption [11]. The production and combustion of transportation fuels also release $\mathrm{CH}_{4}$ and nitrous oxide $\left(\mathrm{N}_{2} \mathrm{O}\right)$ other than $\mathrm{CO}_{2}$ which contributed to the emission of GHGs. Other than using clean fuel alternatives, novel automotive engines with postcombustion emission control devices should be developed to reduce the GHG emissions and improve the efficiency of energy systems [12-14]. The application of biodiesel engine in transportation and power generation sectors has shown development in the past decades, and the latest research development trend is seeking a novel ICE with low emission [15-17], energy savings [18,19], and high-efficiency performance [20-22]. 
Biodiesel engines have an excellent reputation for low fuel consumption, high reliability, and high durability due to their high thermal brake performance, high compression ratio, and lower air-fuel mix $[19,23,24]$. However, both diesel and biodiesel fuels have their respective limitations in producing a higher $\mathrm{NO}_{\mathrm{x}}$, which leads to poor combustion performance [25-27]. Thus, to overcome these limitations, the addition of fuel additives is gaining much attention to improve the oxidation characteristics of biodiesel. The blending of diesel/biodiesel with fuel additives could improve combustion performance and reduce GHG emissions effectively. Nanofluid is a potential fueladditive candidate and the pioneer researcher who suggested it was Choi [28]. Nanofluid is a two-phase colloidal mixture consisting of nano-sized particles (nanoparticles) dispersing in a base liquid. Nanoparticles are generally known as particles with sizes approximately between 1 and $100 \mathrm{~nm}$. Rheological behaviour and thermophysical properties of the base fluid would be significantly affected when nanoparticles are dispersed into the base fluid.

This study presents recent research findings of the properties of nanoparticles as an additive in diesel/biodiesel fuels. The present study compares the combustion performance and emission characteristics of ICEs with different types of diesel/biodiesel-nanoparticle blends. Currently, metal oxides like cerium oxide $\left(\mathrm{CeO}_{2}\right)$, aluminium oxide $\left(\mathrm{Al}_{2} \mathrm{O}_{3}\right)$, copper oxide $(\mathrm{CuO})$, silver oxide $\left(\mathrm{Ag}_{2} \mathrm{O}\right)$, iron oxide $\left(\mathrm{Fe}_{2} \mathrm{O}_{3}\right)$, titanium oxide $\left(\mathrm{TiO}_{2}\right)$, silicon $(\mathrm{Si})$, zinc oxide $(\mathrm{ZnO})$, and magnesium $(\mathrm{Mg})$ and nonmetal oxides like carbon nanotubes (CNTs), multiwall CNTs (MWCNTs), graphene oxide (GO), etc. are among the most widely used fuel-additive nanoparticles in diesel/ biodiesel fuel.

The concentration of nanoparticles required for a stable dispersion is also considered in this article. It is well known that the use of different types of nanoparticles in different diesel/biodiesel mixtures can yield different results. For example, it will affect the engine performances, including brake-specific fuel consumption (BSFC), brake power (BP), brake heat efficiency (BTE), engine torque, and toxic gas emissions including $\mathrm{CO}$, $\mathrm{NO}_{\mathrm{x}}$, and particulate matter (PM). To the best of the author's knowledge, very few review papers were published on the fuel consumption and combustion performance of diesel/biodiesel with the addition of nanoparticle-based fuel additives in an ICE.

Hence, the authors aim to provide an extensive review by comparing the combustion, emission, and performance characteristics of the nanofuel additives diesel/ biodiesel blends. First, the renewable energies to control GHGs were briefed in the introduction section. This was followed by a brief review of the stability of nanoparticles in a base fluid. Third, reports the effect of different types of additives blended on the fuel properties and engine performance using the most widely used nanoparticles. That is, metal oxides, such as $\mathrm{CeO}_{2}, \mathrm{Al}_{2} \mathrm{O}_{3}, \mathrm{CuO}, \mathrm{Ag}_{2} \mathrm{O}$, $\mathrm{Fe}_{2} \mathrm{O}_{3}, \mathrm{TiO}_{2}, \mathrm{Si}, \mathrm{ZnO}$, and $\mathrm{Mg}$, and non-metal oxides, such as CNT, MWCNT, and GO, were reviewed as potential additives in fuels. The research works of literature were sourced from Elsevier's' ScienceDirect, Google Scholar, and ISI Web of Science. For sourcing information, many keywords have been used. The keywords include nanoparticles, ICE, diesel/biodiesel, fuel properties, combustion efficiency, and emission control. In identifying the possible articles, more than two of the keywords were used. The select literature included peer-reviewed studies, which contributed significantly to the field of study. Elsevier's Mendeley reference management programme was also used to gather references from the selected articles. All of the findings obtained from these articles are presented in a tabular form. As a whole, this review article will help the researchers from the nanotechnology field and industrial engine manufacturers to gather a quick report on the emission issues and engine performance of different diesel/biodiesel fuel blends.

\section{Stability of nanoparticles in a base fluid}

Generally, nanofluid has high surface energy owing to its large surface area, which tends to promote agglomeration and form micro-sized particles before deposition. For both scientific and practical applications, a stable and homogeneous nanofluid suspension is a crucial phenomenon. Stability plays a vital role in the production of nanofluid as it will affect its performance as a heat carrier and thermophysical properties. To promote a better stability of nanoparticles in a base fluid, many methods have been reported in the literature including ultrasonication, surface modification, the addition of surfactants, and $\mathrm{pH}$ control.

From the literature, several previous studies investigated the effectiveness of ultrasonic dispersion in promoting and improving the stability of nanoparticles. A study by Hong et al. [29] reported that the stability of nanofluids can be enhanced with longer sonication time. From their results, it was revealed that prolonging the sonication time helps to reduce the agglomeration of 
particles. Amrollahi et al. [30] reported similar observations in their experiments. Both studies agreed that longer sonication times improved the stability of nanoparticles. In 2012, Ruan and Jacobi [31] reported that the ultrasonic method could effectively break down the particle agglomerates and promote a stable and better dispersion of nanoparticles in the base fluids. Based on their results, the thermal thermophysical properties of MWCNT-ethylene glycol nanofluid were found to be highly dependent on the sonification time.

Similar conceptual work was also carried out by Chung et al. [32]. By using two different ultrasonic dispersion methods of horn and bath, the effectiveness of both ultrasonic methods in dispersing the $\mathrm{ZnO}$ nanoparticles in the water medium was compared. From the findings, the ultrasonic horn method was found to be more effective in achieving a faster reduction rate, smaller colloidal particle size, and higher sedimentation rates. Unfortunately, the optimum sonication time varied for different types of nanoparticles and base fluids. A study on the homogeneous dispersion of nanoparticles in nanofluids was performed by Hwang et al. [33]. A stable colloidal mixture consisting of both $\mathrm{CB}$ and $\mathrm{Ag}$ nanoparticles was prepared from a two-step method using a stirrer, ultrasonic bath, ultrasonic disruptor, and high-pressure homogenizer. Sodium dodecyl sulfate (SDS) and oleic acid were used as the surfactants to improve the colloidal stability. From the results, the nanoparticles' colloidal prepared from the high-pressure homogenizer possessed the highest stability. With the use of a high-pressure homogenizer, the agglomerated particles can easily break off and separate.

Surfactants are the chemical compounds added to nanoparticles, which help to reduce the surface tension of the nanofluid and increase the absorption of particles. Some literature discussed the use of surfactants for a slower deposition rate; however, in some cases, the proper type of surfactants should be applied to the particles. In the literature, only a few types of surfactant such as hexadecyltrimethylammonium bromide/cetyl trimethyl ammonium bromide (CTAB) [34-37], sodium dodecylbenzene sulfonate (SDBS) $[34,38,39]$, SDS [35,40,41], polyoxyethylene(10)nonylphenyl ether (TX-10) [34], polyvinyl chloride-polyvinyl pyrrolidone (PVP) [38,41,42], salt and oleic acid [33], dodecyltrimethylammonium bromide [39], gum Arabic [35,40], etc. were reported and used in different types of nanofluids. Li et al. [34] prepared the nanofluids from $\mathrm{Cu}-\mathrm{H}_{2} \mathrm{O}$ with and without the addition of dispersant. Different types of surfactants including TX10 (a non-ionic surfactant), CTAB (a cationic surfactant), and SDBS (an anionic surfactant) were used to modify the surface functionality of $0.1 \% \mathrm{Cu}-\mathrm{H}_{2} \mathrm{O}$ nanoparticles. The

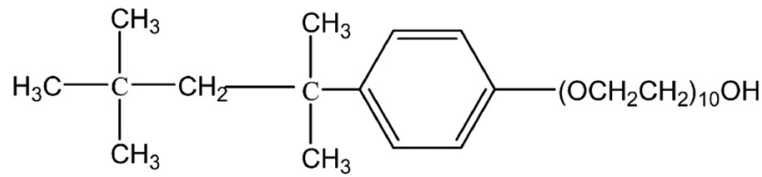

(a)

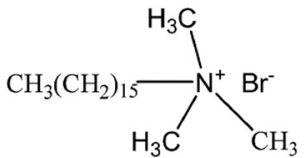

(b)

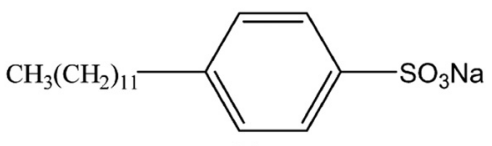

(c)
Figure 1: Chemical structures of surfactants: (a) TX-10; (b) CATB; (c) SDBS [34].

chemical structure of the surfactant can be seen in Figure 1. From the results, it was found out that the optimum concentrations of TX-10, CTAB, and SDBS in yielding better stability for $0.1 \%$ copper nano-suspension were $0.43 \%$, $0.05 \%$, and $0.07 \%$, respectively. Li et al. [39] also reported similar observations in their experiments.

In 2018, Nema et al. [37] used CTAB to prepare $\mathrm{Al}_{2} \mathrm{O}_{3}$ nanoparticles as a nanofuel additive. They performed the study in a dual-blend biodiesel-fuelled compressionignition (CI) engine using $\mathrm{Al}_{2} \mathrm{O}_{3}$ nanoparticles. The $\mathrm{Al}_{2} \mathrm{O}_{3}$ nanoparticles were found to be stable and well dispersed in the base fluid.

Sahooli et al. [42] incorporated a PVP surfactant to prepare a stable $\mathrm{CuO} /$ water nanofluid. The nanofluid was prepared from different $\mathrm{pH}$ values and PVP concentrations. Based on their findings, the $\mathrm{CuO} /$ water nanofluid had excellent colloidal stability with the optimum $\mathrm{pH}$ and PVP concentration of 8 and 0.095, respectively. Xia et al. [41] investigated the colloidal stability of $\mathrm{Al}_{2} \mathrm{O}_{3}$ in deionized water using PVP. In their study, the effect of PVP and SDS on the thermal conductivity of the $\mathrm{Al}_{2} \mathrm{O}_{3} /$ de-ionized water nanofluid was investigated and PVP demonstrated a better dispersion and stability performance than SDS. The optimal concentration ratio of surfactant mass fraction and particle volume fraction were found at the highest thermal conductivity of the nanofluid, where the ratio was partly associated with the particle size, and it decreased with the increase in particle volume fraction. The addition of surfactant is widely adopted to improve the dispersion of nanoparticles in a base fluid and to minimize the coagulation/agglomeration of particles. Figure 2 shows the influence of surfactants on the thermal conductivity of $\mathrm{Al}_{2} \mathrm{O}_{3} /$ de-ionized water nanofluids with different particle sizes.

However, the addition of surfactants can cause some problems including the function of this method in improving the stability of nanofluids, which cannot be applied to 

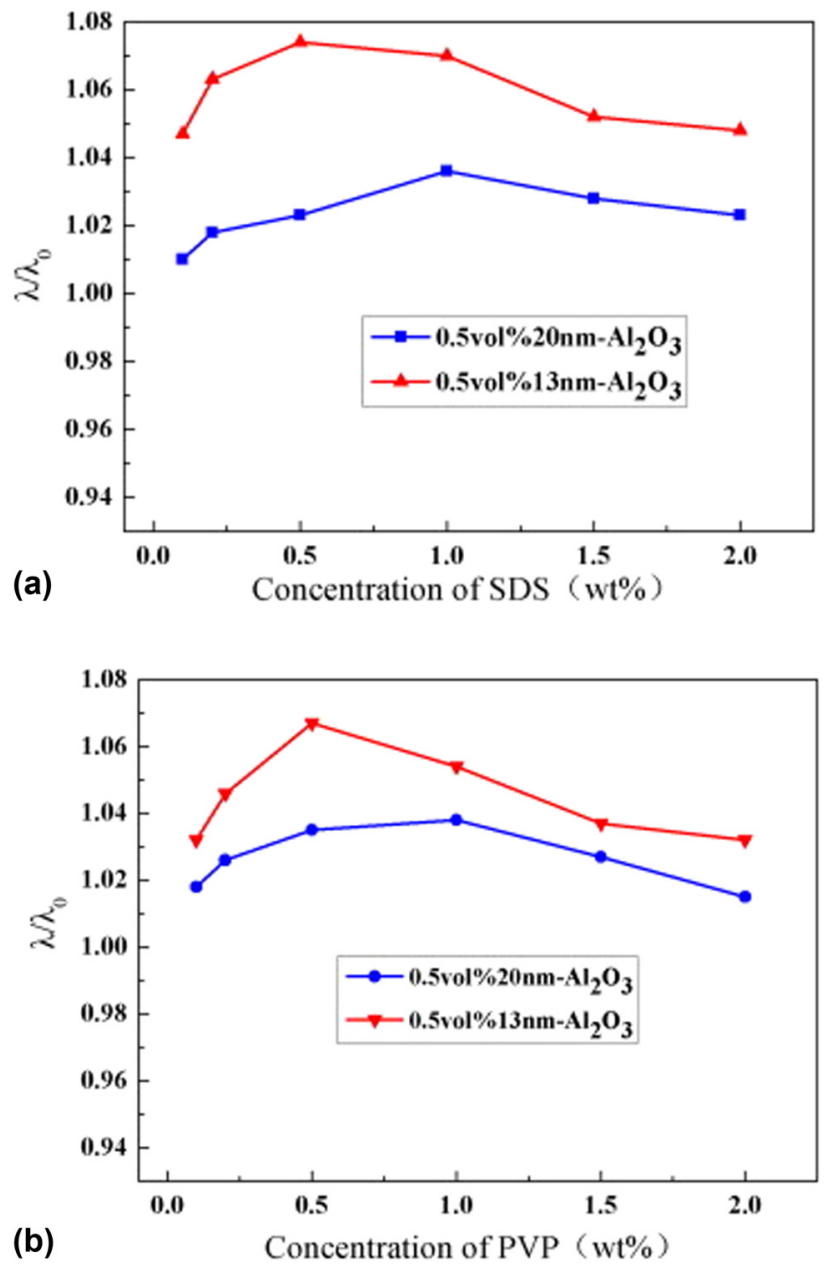

Figure 2: Influence of (a) SDS and (b) PVP concentration on the thermal conductivity of $\mathrm{Al}_{2} \mathrm{O}_{3} /$ de-ionized nanofluids with different particle size under room temperature [41].

nanofluids operating under high temperatures due to the possible bond breakdown between the surfactant and nanoparticles [43,44]. Chen et al. [45] studied the stability and thermal conductivity properties of CNT nanofluids stabilized by a cationic Gemini surfactant. From their finding, it was concluded that a high concentration of surfactants did not improve the thermal conductivity of nanofluids. Besides, the addition of surfactants increased the thermal resistance of the nanoparticle in the base fluids, which led to a poor thermal conductivity performance [43].

\section{Effect of nanoparticles on fuel properties}

The fuel properties are one of the significant factors that determine the quality of the fuel mixing and combustion process. Recently, the addition of nanoparticles has been considered as an advantageous approach in enhancing the fuel properties. Numerous researchers have tested fuel properties by adding different types of nanoparticles in various diesel/biodiesel fuels [37,46-56]. Furthermore, the quality of the fuel mixing and combustion process was evaluated by studying their effects on different features including kinematic viscosity, caloric value, flash point, density, number of cetane, etc. Table 1 compares the physical properties of diesel/biodiesel blend with and without nano-additives.

An experimental investigation of $\mathrm{NO}_{\mathrm{x}}$ reduction in a grapeseed oil biodiesel-fuelled CI engine was performed by Praveena et al. [46,47]. From their study, two different types of nano-additives, namely, $\mathrm{CeO}_{2}$ and $\mathrm{ZnO}$, were used to test the physical properties of the fuel under the American Society for Testing and Materials (ASTM) code. The calorific value of $\mathrm{ZnO}$ was found to be higher than that of $\mathrm{CeO}_{2}$. The low calorific values of $\mathrm{CeO}_{2}$ caused an increase in BSFC. No significant effect was found in the density, pour, cloud points, and kinematic viscosity due to the addition of $\mathrm{CeO}_{2}$ nanoparticles in the grapeseed oil biodiesel fuel. The experimental results were in good agreement with that obtained by Karthikeyan et al. [48] who also investigated the addition of $\mathrm{CeO}_{2}$ (50 and $100 \mathrm{~nm}$ ) nanoparticles in a grapeseed oil biodiesel fuel. However, there was a slight improvement in the flashpoint and calorific value between Praveena [46,47] and Karthikeyan [48]. As a result, the addition of $\mathrm{CeO}_{2}$ nanoparticles' additive exhibited a significant improvement in the performance of and a reduction in harmful emissions as compared to the B20 ( $20 \%$ biodiesel $+80 \%$ diesel).

Ang et al. [49] prepared the diesel fuel blends by using $\mathrm{Al}_{2} \mathrm{O}_{3}$, CNT, and $\mathrm{SiO}_{2}$ nanoparticles with dosing levels of 25,50 , and $100 \mathrm{ppm}$. The physical fuel properties were tested with the engine loads of $0 \%, 25 \%, 50 \%, 75 \%$, and $100 \%$ using ASTM code under a constant engine speed of $1,800 \mathrm{rpm}$. It was observed that the addition of $\mathrm{Al}_{2} \mathrm{O}_{3}$ nanoparticles increased the density and calorific value of the blend with a viscosity reduction in DA25 (diesel fuel $1 \mathrm{~kg}+\mathrm{Al}_{2} \mathrm{O}_{3} 25 \mathrm{mg}$ ). As expected, a significant increment in the viscosity was observed when the concentration of nanoparticles increased. On the contrary, the addition of CNT did not affect the fuel density substantially and showed a reduction in viscosity due to the lubricity of carbon atoms. Yet, the calorific value was found to be increased due to the higher carbon content. Meanwhile, the $\mathrm{SiO}_{2}$ blends displayed a lower fuel density with no significant change in the calorific value as compared to diesel fuel with a lower viscosity characteristic.

In a different study, Rolvin et al. [52] prepared the diesel fuel blend from $\mathrm{TiO}_{2}$ nanoparticles with a dosing level 
Table 1: Comparison between fuel properties of nanoparticles doped in diesel/biodiesel

\begin{tabular}{|c|c|c|c|c|c|c|c|c|}
\hline \multicolumn{2}{|c|}{ Authors } & \multirow[t]{2}{*}{ Base fuel } & \multirow[t]{2}{*}{ Nanoparticles } & \multicolumn{5}{|c|}{ Fuel properties } \\
\hline & & & & $\begin{array}{l}\text { Viscosity } \\
\text { (cSt) }\end{array}$ & Flashpoint $\left({ }^{\circ} \mathrm{C}\right)$ & $\begin{array}{l}\text { Calorific } \\
\text { value } \\
(\mathrm{MJ} / \mathrm{kg})\end{array}$ & $\begin{array}{l}\text { Density } \\
\left(\mathrm{kg} / \mathrm{m}^{3}\right)\end{array}$ & Cetane No. \\
\hline \multirow[t]{3}{*}{1} & \multirow[t]{3}{*}{ Praveena et al. [46] } & \multirow{3}{*}{$\begin{array}{l}\text { Grapeseed oil } \\
\text { biodiesel (GSO) }\end{array}$} & - & 4.06 & - & 39.07 & - & 55 \\
\hline & & & $\mathrm{CeO}_{2} 100$ & 4.47 & - & 38.76 & - & 57 \\
\hline & & & ZnO 100 & 4.42 & - & 38.9 & - & 59 \\
\hline \multirow[t]{5}{*}{2} & \multirow[t]{5}{*}{ Praveena et al. [47] } & \multirow[t]{5}{*}{ GSO biodiesel } & - & 4.06 & - & 39.07 & 845 & 55 \\
\hline & & & ZnO 50 & 4.40 & - & 38.78 & 849 & 58 \\
\hline & & & ZnO 100 & 4.42 & - & 38.9 & 850 & 59 \\
\hline & & & $\mathrm{CeO}_{2} 50$ & 4.45 & - & 38.55 & 852 & 56 \\
\hline & & & $\mathrm{CeO}_{2} 100$ & 4.47 & - & 38.76 & 853 & 57 \\
\hline \multirow[t]{3}{*}{3} & \multirow{3}{*}{$\begin{array}{l}\text { Karthikeyan } \\
\text { et al. [48] }\end{array}$} & \multirow[t]{3}{*}{ GSO biodiesel } & - & 5.554 & 38 & 37.02 & 841 & - \\
\hline & & & $\mathrm{CeO}_{2} 50$ & 5.556 & 39 & 38.38 & 843 & - \\
\hline & & & $\mathrm{CeO}_{2} 100$ & 5.559 & 39 & 38.96 & 846 & - \\
\hline \multirow[t]{10}{*}{4} & \multirow[t]{10}{*}{ Ang et al. [49] } & \multirow[t]{10}{*}{ Diesel fuel } & - & 4.56 & - & 48.58 & 841 & 56.0 \\
\hline & & & $\mathrm{Al}_{2} \mathrm{O}_{3} 25$ & 3.70 & - & 48.20 & 853 & 55.4 \\
\hline & & & $\mathrm{Al}_{2} \mathrm{O}_{3} 50$ & 3.81 & - & 49.32 & 856 & 55.3 \\
\hline & & & $\mathrm{Al}_{2} \mathrm{O}_{3} 100$ & 4.12 & - & 49.77 & 873 & 55.4 \\
\hline & & & CNT 25 & 3.99 & - & 49.09 & 841 & 54.7 \\
\hline & & & CNT 50 & 3.86 & - & 50.18 & 846 & 54.8 \\
\hline & & & CNT 100 & 3.83 & - & 51.27 & 850 & 54.9 \\
\hline & & & $\mathrm{SiO}_{2} 25$ & 4.26 & - & 47.31 & 845 & 55.0 \\
\hline & & & $\mathrm{SiO}_{2} 50$ & 3.98 & - & 47.78 & 835 & 55.2 \\
\hline & & & $\mathrm{SiO}_{2} 100$ & 4.26 & - & 48.60 & 836 & 55.7 \\
\hline \multirow[t]{3}{*}{5} & \multirow[t]{3}{*}{ Gumus et al. [50] } & Diesel fuel & - & 3.6 & 60 & - & 833.5 & 53.8 \\
\hline & & & CuO 50 & 3.5 & 66 & - & 834.1 & 54.5 \\
\hline & & & $\mathrm{Al}_{2} \mathrm{O}_{3} 50$ & 3.5 & 68 & - & 834.3 & 54.4 \\
\hline 6 & Sahoo and Jain [51] & Diesel fuel & - & 3.6 & 60 & 42 & 833 & - \\
\hline & & & $\mathrm{CuO}$ & 3.5 & 66 & 42.43 & 834.1 & - \\
\hline 7 & Rolvin et al. [52] & Diesel fuel & - & 2.981 & 51 & 41.794 & 697.2 & - \\
\hline & & & $\mathrm{TiO}_{2}$ & 3.165 & 72 & 42.042 & 700.2 & - \\
\hline 8 & Devarajan et al. [53] & Palm stearin biodiesel & - & 4.28 & 140 & 37.51 & 844 & - \\
\hline & & & $\mathrm{AgO} 5$ & 3.86 & 134 & 38.35 & 804 & - \\
\hline & & & Ag0 10 & 3.71 & 132 & 38.54 & 797 & - \\
\hline 9 & Perumal and & Pongamia biodiesel & - & 3.02 & 69 & 43.68 & 824 & - \\
\hline & Ilangkumaran [54] & & CuO 50 & 4.79 & 67 & 43.78 & 835 & - \\
\hline & & & CuO 100 & 4.85 & 66 & 43.82 & 846 & - \\
\hline 10 & Sajin et al. [55] & Mango seed biodiesel & - & 3.8 & 165 & 38.125 & 880 & 58 \\
\hline & & & $\mathrm{ZnO}(20 \mathrm{~nm})$ & 3.7 & 168 & 38.25 & 820 & 58 \\
\hline & & & $\mathrm{ZnO}(40 \mathrm{~nm})$ & 3.6 & 171 & 38.75 & 790 & 59 \\
\hline 11 & Lenin et al. [56] & Diesel fuel & - & 2.7 & 48 & - & - & - \\
\hline & & & $\mathrm{MnO}$ & 2.53 & 44 & - & - & - \\
\hline & & & $\mathrm{CuO}$ & 2.24 & 40 & - & - & - \\
\hline 12 & Tewari et al. [57] & Honge oil methyl & - & 5.6 & 170 & 36.016 & - & - \\
\hline & & ester & CNT25 & 5.7 & 166 & 34.56 & - & - \\
\hline & & & CNT50 & 5.8 & 164 & 35.1 & - & - \\
\hline 13 & Narasiman & Sardine oil methyl & - & 4.5 & 58 & 37.405 & 890 & 45 \\
\hline & et al. [58] & ester (SOME) & $\mathrm{CeO}_{2} 25 \mathrm{ppm}$ & 5.6 & 191 & 45.365 & 894 & 56 \\
\hline 14 & Sathiyamoorthi & Neem oil biodiesel & - & 3.74 & 65 & 41.9 & 828 & 43.5 \\
\hline & et al. [59] & & $\mathrm{CeO}_{2} 50 \mathrm{ppm}$ & 3.71 & 66 & 41.94 & 830 & 43.7 \\
\hline 15 & Gharehghani & Diesel-biodiesel fuel & - & 2.9 & 82 & 44.572 & - & - \\
\hline & et al. [60] & blend & $7 \%$ water & 3.92 & 74 & 42.488 & - & - \\
\hline & & & $\mathrm{CeO}_{2} 90 \mathrm{ppm}$ & 3.88 & 77 & 42.382 & - & - \\
\hline 16 & Annamalai et al. [61] & Lemongrass oil & - & 4.6 & 55 & 37 & 905 & 48 \\
\hline & & emulsion fuel & $5 \%$ water & 4.67 & 74 & 35.8 & 906 & 46.3 \\
\hline
\end{tabular}


Table 1: Continued

\begin{tabular}{|c|c|c|c|c|c|c|c|c|}
\hline \multicolumn{2}{|c|}{ Authors } & \multirow[t]{2}{*}{ Base fuel } & \multirow[t]{2}{*}{ Nanoparticles } & \multicolumn{5}{|c|}{ Fuel properties } \\
\hline & & & & $\begin{array}{l}\text { Viscosity } \\
\text { (cSt) }\end{array}$ & Flashpoint $\left({ }^{\circ} \mathrm{C}\right)$ & $\begin{array}{l}\text { Calorific } \\
\text { value } \\
(\mathrm{MJ} / \mathrm{kg})\end{array}$ & $\begin{array}{l}\text { Density } \\
\left(\mathrm{kg} / \mathrm{m}^{3}\right)\end{array}$ & Cetane No. \\
\hline & & & $\mathrm{CeO}_{2} 30 \mathrm{ppm}$ & 4.99 & 67 & 36.2 & 916.4 & 48.8 \\
\hline \multirow[t]{5}{*}{17} & Nanthagopal & Calophyllum & - & 4.72 & 122 & 38 & 868.6 & 52 \\
\hline & et al. [62] & inophyllum biodiesel & ZnO 50 ppm & 4.76 & 123 & 37.02 & 871.1 & 54 \\
\hline & & & $\mathrm{ZnO} 100 \mathrm{ppm}$ & 4.78 & 126 & 37.32 & 872.4 & 56 \\
\hline & & & $\mathrm{TiO}_{2} 50 \mathrm{ppm}$ & 4.73 & 123 & 37.12 & 869.2 & 53 \\
\hline & & & $\mathrm{TiO}_{2} 100 \mathrm{ppm}$ & 4.75 & 124 & 37.54 & 870.4 & 55 \\
\hline \multirow[t]{2}{*}{18} & Anchupogu & Calophyllum & - & 3.56 & 69 & 40.92 & 843.3 & 53.85 \\
\hline & et al. [63] & inophyllum biodiesel & $\mathrm{Al}_{2} \mathrm{O}_{3} 40 \mathrm{ppm}$ & 3.64 & 64 & 41.435 & 858 & 54.58 \\
\hline \multirow[t]{2}{*}{18} & Nithya et al. [64] & Canola biodiesel & - & 4.8 & - & - & 915 & 42 \\
\hline & & & $\mathrm{TiO}_{2} 300 \mathrm{ppm}$ & 3.4 & - & - & 840 & 56 \\
\hline \multirow[t]{7}{*}{19} & Najafi [65] & Diesel-biodiesel fuel & - & 4.24 & & 45.72 & 835 & 46 \\
\hline & & blend & $\mathrm{Ag} 40 \mathrm{ppm}$ & 4.36 & & 46.44 & 854.7 & 47 \\
\hline & & & $\mathrm{Ag} 80 \mathrm{ppm}$ & 4.4 & & 46.68 & 855.3 & 48 \\
\hline & & & $\mathrm{Ag} 120 \mathrm{ppm}$ & 4.49 & & 46.92 & 858.8 & 50 \\
\hline & & & CNT 40 ppm & 4.74 & & 47.12 & 879.9 & 57 \\
\hline & & & CNT 80 ppm & 4.82 & & 48.02 & 884.3 & 59 \\
\hline & & & CNT 120 ppm & 4.91 & & 48.68 & 891.6 & 61 \\
\hline
\end{tabular}

of $500 \mathrm{ppm}$. The results demonstrated that the addition of nanoparticles to the base fuel improved the fuel properties including fire point, viscosity, density, and calorific value. Gumus et al. [50] and Sahoo and Jain [51] also concluded that the nanoparticle additives possessed better fuel characteristics like flash point and calorific value. A lower BSFC was attributed to the higher calorific value [62].

From an experimental investigation performed by Sajin et al. [55], the influence of the size of $\mathrm{ZnO}$ nanoparticles on the physical properties of mango seed biodiesel was investigated. From the results, the biodiesel blended with $40 \mathrm{~nm}$ $\mathrm{ZnO}$ nanoparticles had a higher calorific value and cetane value and the addition of nanoparticles in the biodiesel promoted better combustion performance.

\section{Effects of metal oxide nanoparticles as additives in diesel/biodiesel fuel on the performance, combustion, and emission characteristics}

The main purposes of adding nanoparticles into the diesel/ biodiesel fuel are to promote a high surface-to-volume ratio and increase the number of reactive surfaces. It allows the nanoparticles to act as an effective chemical catalyst which improves the mixing pattern of fuel with air and the fuel combustion performance, subsequently leading to a fully combusted chemical catalyst.

\section{1 $\mathrm{CeO}_{2}$}

$\mathrm{CeO}_{2}$ can be served as an oxygen buffer to simultaneously induce the oxidation of hydrocarbons (HCs) and reduction of nitrogen oxide emission [66,67]. Several studies and reviews have explored the effects of $\mathrm{CeO}_{2}$ nanofuel additives on the performance, combustion, and emission characteristics of $\mathrm{CI}$ engine.

In 2015, Narasiman et al. [58] investigated the effects of $\mathrm{CeO}_{2}$ nanoparticle's additive in diesel and sardine oil methyl ester (SOME). The mass fracture of nanoparticles used was $25 \mathrm{ppm}$. Throughout the experiments, a single four-stroke diesel engine was used at different loads under a constant speed. From the test, it was revealed that the nanoparticles could be used as an additive in diesel and biodiesel to induce complete fuel combustion and significantly improve the exhaust emissions.

Sathiyamoorthi et al. [59] investigated the performance, emission, and combustion characteristics of a single cylinder with two modified fuel blends: BN20 (biodiesel from neem oil) and $\mathrm{CeO}_{2}$ nanoparticle's additive blended in BN2O. Ultrasonicator was used to mix $\mathrm{CeO}_{2}$ 
nano-additives with BN20 to promote better colloidal stability. The addition of nanoparticle additives promoted a higher BSFC and BTE as compared to the standard diesel fuel. The emissions of $\mathrm{NO}_{\mathrm{x}}$, smoke, $\mathrm{HC}$, and $\mathrm{CO}$ were found to significantly decrease after the nanoparticle's additive was added into the BN20 fuel. Experimental results also revealed that a higher amount of cylinder pressure and heat were released when $\mathrm{CeO}_{2}$ nanoparticles were added into BN20 fuel.

A significant study by Gharehghani et al. [60] included the effect of water and $\mathrm{CeO}_{2}$ nanoparticles on engine performance, combustion, and emission characteristics of diesel/biodiesel fuels. The influence of water and nanoadditive in diesel/biodiesel fuel was found to improve the overall combustion quality. The experimental results were in good agreement with that obtained by Khalife et al. [68] and Mei et al. [69].

Sathiyamoorthi et al. [70] conducted a novel study to evaluate the performance, combustion, and emission characteristics of neat lemongrass oil biodiesel. The entire research was performed in the diesel engine using emulsified LGO25 (75\% diesel volume and 25\% lemongrass oil volume), a mixture of $\mathrm{CeO}_{2}$-emulsified $\mathrm{LGO} 25$, and a mixture of diethyl ether (DEE)-emulsified LGO25 with an exhaust gas recirculation (EGR). All of the nanofluid blends were compared to the standard diesel and LGO25 fuel. From the results, a significant improvement in $\mathrm{NO}_{\mathrm{x}}$ and smoke emission was observed in the mixture of DEE-emulsified LGO25 and EGR. The $\mathrm{NO}_{\mathrm{x}}$ and smoke emissions were found to be reduced by 30.72 and $11.2 \%$, respectively. In the context of $\mathrm{HC}$ and $\mathrm{CO}$ emissions, both were reduced by 18.18 and $33.31 \%$, respectively, whereas the BTE and BSFC increased by 2.87 and $10.8 \%$, respectively. The combustion characteristics such as cylinder pressure and heat release rate increased by 4.46 and $3.29 \%$, respectively, as compared to the emulsified LGO25. These findings are in line with those found in the literature and the nano-additive was demonstrated as an oxygen buffer to promote a better combustion and emission control efficiency [71].

Pandey et al. [72,73] investigated the effect of $\mathrm{CeO}_{2}$ nanoparticles on the combustion performance and emission of Karanja oil biodiesel. From the results, Karanja oil biodiesel with $5 \mathrm{wt} \%$ of nano-additive demonstrated enhanced engine performance with a substantial reduction in particulate emissions including lower emissions of $\mathrm{NO}_{\mathrm{x}}(14-25 \%)$ and $\mathrm{PM}$ as compared to diesel fuel. Besides, the addition of nano-additive to Karanja oil biodiesel caused a slower heat release rate as compared to the standard diesel. It possessed a higher cetane number than diesel [66] and thus had a shorter delay in the ignition as compared to petrol. Apart from that, their results were in good agreement with that reported by Babu and Praneeth [74].

Ananda et al. [75] demonstrated the emission reduction of an ethanol-gasoline blend using $\mathrm{CeO}_{2}$ nanoparticles as a fuel additive. From the results, the thermal brake performance of nanoparticle mixtures was found to be improved. In the $\mathrm{CO}$ emission test, the $\mathrm{CO}_{2}, \mathrm{HC}$, and $\mathrm{NO}_{\mathrm{x}}$ emissions reduced significantly with a substantial increment in $\mathrm{O}_{2}$ concentration in all blends. From the combustion analysis, the gas pressure of nanoparticle blends was higher as compared to that of the pristine fuel.

Recently, Janakiraman et al. [76] examined the combustion performance and emissions of $\mathrm{CeO}_{2}, \mathrm{ZrO}_{2}$, and $\mathrm{TiO}_{2}$ as nanoparticle additives. It was observed that the $\mathrm{HC}$ of $\mathrm{TiO}_{2}, \mathrm{CeO}_{2}$, and $\mathrm{ZrO}_{2}$ blended with $\mathrm{B} 20$ (20\% Garcinia gummi-gutta biodiesel $+80 \%$ diesel) were lower than the neat B20 by $6.39,3.99$, and $5.64 \%$, respectively, under maximum load condition. Furthermore, B20 blend with $\mathrm{TiO}_{2}$ had a better combustion efficiency, lower CO, unburned HC (UBHC), smoke, and diesel fuel combustion. The addition of nanoparticles into the blends was found to contribute a declining trend in the $\mathrm{HC}$ emissions due to the high availability of oxygen content and lower activation energy discharged by the nanoparticles [55,69,77-80]. All the nanoparticle blends exhibited a lower brake specific energy consumption (BSEC) as compared to B100 by 23.42, 22.11, and $19.8 \%$, under the maximum load condition. The reduction of fuel blends in BSEF is shown in Figure 3. The study from Senthil and Ramesh [80] evaluated the effect of ginger grass oil biodiesel on the performance, combustion, and emission characteristics using $\mathrm{CeO}_{2}$ as a fuel additive. It was found out that the HC content increased with a higher concentration of ginger grass oil in the blends.

Thangavelu et al. [81] explored the potential of $\mathrm{CeO}_{2}$ nanoparticles as a fuel additive in a four-stroke singlecylinder water-cooled compression ignition engine with the volumetric proportions of 5, 10, 15, and $20 \%$. From the study, a significant reduction in the emission of $\mathrm{HC}$ by $3 \%$, smoke by $7.7 \%$, and CO by $1.33 \%$ was found as compared to that of the conventional diesel. It was concluded that $\mathrm{B} 5 \mathrm{D} 85+\mathrm{CeO}_{2}(100 \mathrm{ppm})$ fuel blend had the best fuel ratio for a $\mathrm{CI}$ engine due to the high engine efficiency, low particle emission, and better combustion. Thus, it can be served as a suitable alternative fuel for the $\mathrm{CI}$ engine.

$\mathrm{CeO}_{2}$ nanoparticles and iron dope (10 and 20\% iron) were added into the waste cooking oil biodiesel-diesel blend in the study by Hawi et al. [82]. From the results, the $\mathrm{NO}_{\mathrm{x}}$ emission was reduced by $15.7 \%$ with no 


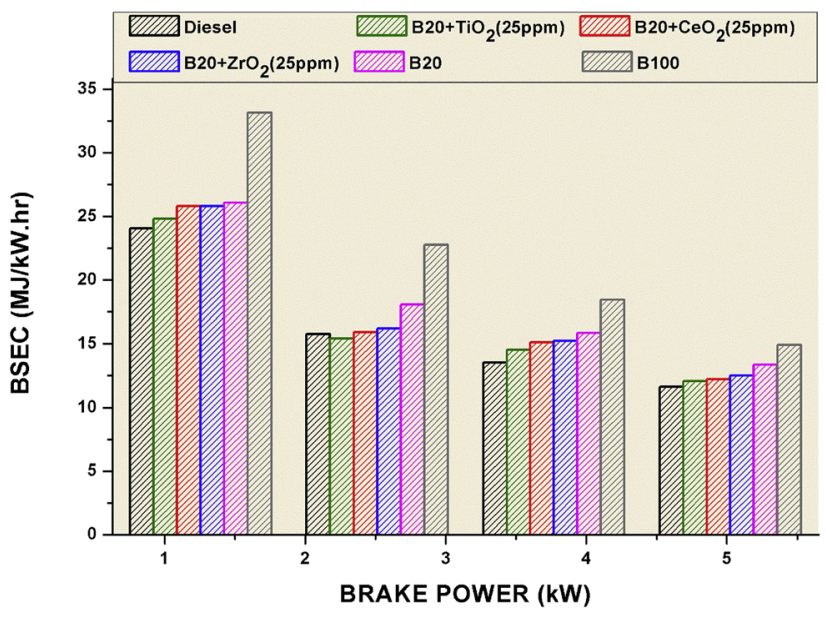

Figure 3: The BSEC for fuel blends with nanoparticles [76].

significant change in the $\mathrm{HC}$ emissions. At the same time, CO emission was reduced by $24.6 \%$ for B 30 and $15.4 \%$ for B30 with nano-additives. From low to medium loads, a lower BSFC was found for the B30 fuel mixture with 10\% $\mathrm{FeCeO}_{2}$ nanoparticles and comparable to $\mathrm{D} 100$ at high loads. In contrast, BTE improved with an increase in engine load. Akram et al. [83] also conducted a study using waste cooking oil diesel/biodiesel. However, in their research, the emission reduction potential in $\mathrm{CO}$, $\mathrm{NO}_{\mathrm{x}}$, and UBHC was investigated using different concentrations of $\mathrm{CeO}_{2}$ nanoparticles and $\mathrm{Ce}_{0.5} \mathrm{Co}_{0.5}$ nanocomposite oxide under full engine load. It was found that $\mathrm{CO}$, $\mathrm{NO}_{\mathrm{x}}$, and UBHC emissions reduced by 18.27, 6.57, and 23.46\%, respectively, when $\mathrm{CeO}_{2}$ (100 ppm) was used. On the contrary, when $\mathrm{Ce}_{0.5} \mathrm{Co}_{0.5}$ nanocomposite oxide (100 ppm) was used, $\mathrm{CO}, \mathrm{NO}_{\mathrm{x}}$, and UBHC emissions reduced by $24.18,13.96$, and $40.74 \%$, respectively. It was observed that the addition of $\mathrm{CeO}_{2}$ nanoparticles led to an increase in the viscosity index of the biodiesel owing to the high catalytic activity $[84,85]$.

Table 2 summarizes the effect of $\mathrm{CeO}_{2}$ nanoparticles in diesel/biodiesel fuel on the performance, combustion, and emission characteristics of the ICE with some undiscussed research works.

\section{$4.2 \mathrm{Al}_{2} \mathrm{O}_{3}$}

In the following section, the effect of $\mathrm{Al}_{2} \mathrm{O}_{3}$ nanoparticles as a fuel additive in diesel/biodiesel blend on the engine performance, combustion, and emission characteristics of the ICE are reviewed and discussed. Nassir and Shahad [87] attempted to examine the impact of $\mathrm{Al}_{2} \mathrm{O}_{3}$ and $\mathrm{TiO}_{2}$ nanoparticles on the combustion phasing of diesel fuel. The addition of nanoparticles improved the fuel properties. For instance, the cetane number enhanced from 51.6 to 54.3 with the addition of $150 \mathrm{ppm}^{2} \mathrm{Al}_{2} \mathrm{O}_{3}$ nanoparticles. The effect of nanoparticles on the delay time and fractioning of heat release (premix and diffusion) was noticeable. From the results, the delay period decreased with higher nanoparticle concentration. The effect of $\mathrm{Al}_{2} \mathrm{O}_{3}$ nanoparticles on viscosity, temperatures, and the cetane number was more prominent than the effect of $\mathrm{TiO}_{2}$. Nevertheless, $\mathrm{TiO}_{2}$ nanoparticles contributed to the most significant reduction in the delay period, which can be attributed to the higher viscosity of $\mathrm{Al}_{2} \mathrm{O}_{3}$.

Sathiamurthi et al. [88] added $50 \mathrm{~nm} \mathrm{Al}_{2} \mathrm{O}_{3}$ nanoparticles into the diesel fuel and evaluated the combustion performance and emission characteristics of the diesel blend in a four-stroke, single-cylinder diesel engine under different load conditions and fuel blends $(0.5 \mathrm{~g}$ and $1 \mathrm{~g}$ of $50 \mathrm{~nm} \mathrm{Al}_{2} \mathrm{O}_{3}$ nanoparticles were blended into $1 \mathrm{~L}$ of diesel fuel). The results obtained were similar to the study done by Venkatesan and Kadiresh [89] even though they used a smaller size of nanoparticles $(40 \mathrm{~nm})$ and different fuel rate $(1$ and $1.5 \mathrm{~g} / \mathrm{L}$ ). These results indicate that particle size has a significant effect on ignition and combustion. The smaller particle sizes showed a greater intensity of reaction. Furthermore, the addition of nanoparticle was found to improve the combustion characteristics and enhanced the surface to volume ratio. Thus, the burning efficiency of the test fuels was promoted as more diesel fuels reacted with the oxidizer. From the results, a significant increase in BTE and a considerable reduction in the $\mathrm{NO}_{\mathrm{x}}$ and UBHC contents of all loads were observed as compared to pure diesel fuel. This could be due to the improved combustion characteristics of nanoparticles and the enhanced air mixing ratio.

Basha [90] also studied the combustion performance of diesel fuel blend with $\mathrm{Al}_{2} \mathrm{O}_{3}$ nanoparticles. The result of the analysis revealed that a significant increase in BTE and a marginal reduction in harmful pollutants including $\mathrm{NO}_{\mathrm{x}}, \mathrm{CO}$, and smoke were observed with the diesel fuel blend in contrast to the pure diesel fuel. The addition of $\mathrm{Al}_{2} \mathrm{O}_{3}$ nanoparticles in diesel fuels boosted the combustion efficiency of the diesel engine. However, many research works are still ongoing to capture potential nanoparticles released from the exhaust to avoid environmental pollution. Kao et al. [91] conducted an experimental investigation in a single-cylinder horizontal diesel engine using $\mathrm{Al}_{2} \mathrm{O}_{3}$ additive diesel fuel with different percentages of water $(3-6 \%)$. A significant reduction in the BSFC and harmful pollutants was observed. The addition of $\mathrm{Al}_{2} \mathrm{O}_{3}$ nanoparticles to the diesel fuel provided a large surface area for interaction between water molecules and 
Table 2: Summary of $\mathrm{CeO}_{2}$ nanoparticle studies as an additive in diesel/biodiesel fuel

\begin{tabular}{|c|c|c|c|c|}
\hline \multicolumn{2}{|c|}{ Authors } & \multirow{2}{*}{$\begin{array}{l}\text { Base fuel } \\
\text { Grapeseed oil biodiesel }\end{array}$} & \multirow{2}{*}{$\frac{\text { Nanoparticles }}{\mathrm{CeO}_{2} \text { and } \mathrm{ZnO}}$} & \multirow{2}{*}{$\begin{array}{l}\text { Mass fraction of nanoparticles } \\
100 \mathrm{ppm}\end{array}$} \\
\hline 1 & Praveena et al. [46] & & & \\
\hline & \multicolumn{4}{|c|}{$\begin{array}{l}\text { Engine performance: } \mathrm{BTE} \text { of } \mathrm{CeO}_{2} \text { and } \mathrm{ZnO} \text { increased by } 1.4 \text { and } 1.71 \% \text { from } 28.8 \text {. } \mathrm{BSFC} \text { of } \mathrm{CeO}_{2} \text { decreased to } 0.30 \mathrm{~kg} / \mathrm{kW} \mathrm{h} \text { and } \mathrm{BSFC} \text { of } \\
\mathrm{ZnO} \text { reduced to } 0.29 \mathrm{~kg} / \mathrm{kWh}\end{array}$} \\
\hline \multirow[t]{2}{*}{2} & Praveena et al. [47] & Grapeseed oil biodiesel & $\mathrm{CeO}_{2}$ and $\mathrm{ZnO}$ & 50 and $100 \mathrm{ppm}$ \\
\hline & \multicolumn{4}{|c|}{$\begin{array}{l}\text { Engine performance: Improved BTE. Reduced BTE by } 29.34 \text { and } 29.23 \% \text { for GSBD ZnO100 and GSBD CeO2100. BSFC improved to } \\
0.31 \mathrm{~kg} \mathrm{~kW}^{-1} \mathrm{~h}^{-1}\end{array}$} \\
\hline \multirow[t]{2}{*}{3} & Karthikeyan et al. [48] & GSO biodiesel & $\mathrm{CeO}_{2}$ & 50 and $100 \mathrm{ppm}$ \\
\hline & \multicolumn{4}{|c|}{ Engine performance: Higher BTE and lower BSFC } \\
\hline \multirow[t]{3}{*}{4} & Narasiman et al. [58] & SOME biodiesel and diesel & $\mathrm{CeO}_{2}$ & $25 \mathrm{ppm}$ \\
\hline & \multicolumn{4}{|c|}{ Engine performance: Lower BTE than B20 } \\
\hline & \multicolumn{4}{|c|}{ Harmful emission: Increase in $\mathrm{NO}_{\mathrm{x}}$ emission and a significant decrease in $\mathrm{HC}$ emission } \\
\hline \multirow[t]{3}{*}{5} & Sathiyamoorthi et al. [59] & Neem oil biodiesel & $\mathrm{CeO}_{2}$ & $50 \mathrm{ppm}$ \\
\hline & \multicolumn{4}{|c|}{ Engine performance: Higher BTE and BSFC as compared to B20 } \\
\hline & \multicolumn{4}{|c|}{ Harmful emission: $\mathrm{NO}_{\mathrm{x}}, \mathrm{Smoke}, \mathrm{HC}$, and $\mathrm{CO}$ emissions significantly reduced } \\
\hline 6 & Gharehghani et al. [60] & Diesel-biodiesel fuel (B5) & $\mathrm{CeO}_{2}$ & 90 ppm \\
\hline
\end{tabular}

Engine performance: BTE for B5W7m (B5 containing 7\% water and nanoparticle) was increased by more than 13.5 and $6 \%$ compared to B5W7 and B5. BSFC was reduced by 8 and $23 \%$

Harmful emission: $\mathrm{CO}$ emission for B5W7m reduced by 42 and $3 \%$ as compared to B5W7 and B5, respectively

7 Khalife et al. [68] $\quad$ Biodiesel/diesel fuel blend (B5) $\quad \mathrm{CeO}_{2} \quad 90 \mathrm{ppm}$

Engine performance: $\mathrm{BSFC}$ reduced by $16 \%$. BTE was increased by $11 \%$

Harmful emission: $\mathrm{CO}, \mathrm{HC}$, and $\mathrm{NO}_{\mathrm{x}}$ emissions reduced by 51,45 , and $27 \%$, respectively, as compared to those of neat biodiesel/ diesel fuel
Mei et al. [69]
Diesel
$\mathrm{CeO}_{2}$
50 and $100 \mathrm{ppm}$

Engine performance: Higher BTE and slight decreased in BSFC

Harmful emission: Harmful pollutants including $\mathrm{HC}, \mathrm{CO}$, and $\mathrm{NO}_{x}$ decreased

9 Sathiyamoorthi et al. [70] Neat lemongrass oil biodiesel $\quad \mathrm{CeO}_{2} \quad 50 \mathrm{ppm}$

Engine performance: Higher BTE and BSFC as compared to B20

Harmful emission: $\mathrm{NO}_{x}$, Smoke, $\mathrm{HC}$, and $\mathrm{CO}$ emissions significantly reduced

10 Annamalai et al. [61] $\quad$ Neat lemongrass oil biodiesel $\quad \mathrm{CeO}_{2} \quad 30 \mathrm{ppm}$

Engine performance: Higher BTE and lower BSFC

Harmful emission: UBHC and CO emission reduced by 35.5 and $16.03 \%$. $\mathrm{NO}_{\mathrm{x}}$ reduced by 24.8 and $20.3 \%$ and smoke by 6.4 and $19.8 \%$ as compared to neat LGO and neat diesel fuel

11 Pandey et al. [72] Karanja oil biodiesel $\quad \mathrm{CeO}_{2} \quad 30,40,45,50$, and 80 ppm

Engine performance: Lower BSFC

Harmful emission: Lower $\mathrm{CO}, \mathrm{CO}_{2}, \mathrm{HC}$, and $\mathrm{NO}_{x}$ emission

12 Pandey et al. [73] Karanja oil biodiesel

Karanja oil biodiesel $\quad \mathrm{CeO}_{2}$

$30,40,45,50$, and $80 \mathrm{ppm}$

Engine performance: Lower BSFC

Harmful emission: Lower $\mathrm{CO}, \mathrm{CO}_{2}, \mathrm{HC}$, and $\mathrm{NO}_{\mathrm{x}}$ emission

13 Babu and Praneeth [74] Karanja biodiesel $\mathrm{CeO}_{2}$

Engine performance: Improvement in BTE

Harmful emission: Lower emissions

14 Ananda et al. [75] Ethanol-gasoline blend $\mathrm{CeO}_{2}$

Engine performance: Improvement in BTE

Harmful emission: Lower emissions

15 Janakiraman et al. [76] Garcinia gummi-gutta biodiesel

Engine performance: Higher BTE and lower BSEF

Harmful emission: Lower $\mathrm{CO}$, lower $\mathrm{NO}_{x}$, and smoke emissions

16 Senthil and Ramesh [80] Ginger grass oil

Engine performance: Higher BTE and lower BSFC

$\mathrm{CeO}_{2} \quad 100,150$, and $200 \mathrm{mg}$

$\mathrm{CeO}_{2}, \mathrm{ZrO}_{2}, \mathrm{TiO}_{2}$

$\mathrm{CeO}_{2} \quad 30 \mathrm{ppm}$

Harmful emission: Lower $\mathrm{CO}_{2}, \mathrm{HC}$, and $\mathrm{NO}_{x}$ emission. All samples have lower $\mathrm{CO}$ emission except for $\mathrm{B} 10$, which was higher at lower load and then decreased at maximum load

17 Thangavelu et al. [81] Waste tyre oil

Engine performance: Improvement in BTE 
Table 2: Continued

\begin{tabular}{|c|c|c|c|c|}
\hline Aut & nors & Base fuel & Nanoparticles & Mass fraction of nanoparticles \\
\hline \multicolumn{5}{|c|}{ Harmful emission: Reduced emissions for $\mathrm{HC}, \mathrm{CO}$, and smoke by $3,1.33$, and $7.7 \%$, respectively } \\
\hline \multirow[t]{3}{*}{18} & Hawi et al. [82] & Waste cooking oil biodiesel & $\mathrm{CeO}_{2}$ & $90 \mathrm{ppm}$ \\
\hline & Engine performan & BSFC and BTE under low to me & pads & \\
\hline & Harmful emission & $\mathrm{n}$ reduced up to $15.4 \%$. No sig & effect on $\mathrm{HC}$ emissions & \\
\hline \multirow[t]{3}{*}{19} & Akram et al. [83] & Waste cooking oil biodiesel & $\mathrm{CeO}_{2}$ and $\mathrm{Ce} 0.5 \mathrm{Co} 0.5$ & $100 \mathrm{ppm}$ \\
\hline & Engine performan & oned & & \\
\hline & $\begin{array}{l}\text { Harmful emission } \\
40.74 \% \text {, respecti }\end{array}$ & $\begin{array}{l}\text { UBHC emissions reduced by } \\
0_{0.5}\end{array}$ & 6.57 , and $23.46 \%$, resp & , for $\mathrm{CeO}_{2}$ and $24.18,13.96$, and \\
\hline \multirow[t]{3}{*}{20} & Selvan et al. [86] & Diesterol fuel & $\mathrm{CeO}_{2}$ and $\mathrm{CNT}$ & 25,50, and $100 \mathrm{ppm}$ \\
\hline & Engine performan & $\mathrm{C}$ and higher BTE & & \\
\hline & $\begin{array}{l}\text { Harmful emission } \\
\text { emission to } 7.2 \%\end{array}$ & $\begin{array}{l}\text { of E20 + CERIA } 50+\text { CNT } 50 \text { in } \\
\text { espectively, as compared to c }\end{array}$ & $\begin{array}{l}\mathrm{CO} \text { emission to } 22.2 \% \\
\text { fuel }\end{array}$ & uced the hydrocarbon and smoke \\
\hline
\end{tabular}

fuel particles. Due to the high surface activity of the water molecules, hydrogen atom decomposes from the water during combustion which promotes complete combustion.

Gumus et al. [50] carried out a study to investigate the influence of $\mathrm{Al}_{2} \mathrm{O}_{3}$ and $\mathrm{CuO}$ nanoparticles in diesel fuel. The nanoparticle fuel blends were prepared from a concentration level of $50 \mathrm{ppm}$ before comparing the performance, combustion, and emission characteristics of the blends with standard diesel fuel. The testing was conducted between 1,200 and 3,600 rpm with an interval of $250 \mathrm{rpm}$. Based on their findings, the BSFC of nanoparticle fuel blend was lower than that of diesel fuel. The BSFC of $\mathrm{CuO}$ and $\mathrm{Al}_{2} \mathrm{O}_{3}$ additives decreased by up to 0.5 and $1.2 \%$, respectively. With the addition of $\mathrm{Al}_{2} \mathrm{O}_{3}$ to pure diesel, $\mathrm{CO}, \mathrm{HC}$, and $\mathrm{NO}_{\mathrm{x}}$ emissions reduced up to 11,13 , and $6 \%$, respectively. On the contrary, the $\mathrm{CO}, \mathrm{HC}$, and $\mathrm{NO}_{\mathrm{x}}$ emissions of $\mathrm{CuO}$ additive reduced up to 5, 8, and $2 \%$, respectively. The presence of excess oxygen and nanoparticles in diesel fuels improved the fuel properties and combustion efficiency, which led to lower BSFC and harmful emissions [92,93].

In another study, Ang et al. [49] demonstrated a significant reduction in BSFC and higher BTE in the diesel fuel blends with $\mathrm{Al}_{2} \mathrm{O}_{3}, \mathrm{CNT}$, and $\mathrm{SiO}_{2}$ nanoparticles. As compared to $\mathrm{Al}_{2} \mathrm{O}_{3}$, and $\mathrm{SiO}_{2}$ blend, the CNT blend exhibited the highest emission reduction of $19.8 \%$ with a $100 \mathrm{ppm}$ of CNT blends with pure diesel (DC100) under 25\% engine load. Similarly, the CNT blend also had the highest reduction in BTE. From the findings of Selvan et al. [88], CNT blends also demonstrated an improvement in BSFC. These results can be ascribed to the higher calorific value of CNT which led to a substantial reduction in BSFC and BTE. However, the findings are in contrast with the results obtained by Raju et al. [94] who investigated the effect of different dosing levels of $\mathrm{Al}_{2} \mathrm{O}_{3}$ and CNT nanoparticles in novel tamarind seed methyl ester (TSME) biodiesel for diesel engine applications. As compared to other samples, the TSME biodiesel with a dosing level of $60 \mathrm{ppm} \mathrm{Al}_{2} \mathrm{O}_{3}$ nanoparticles exhibited better diesel engine characteristics with a lower BSFC value. This can be explained by the oxygen content of $\mathrm{Al}_{2} \mathrm{O}_{3}$ in TSME biodiesel. Besides, the addition of nanoparticles showed a remarkable improvement in exhaust emissions except for $\mathrm{NO}_{\mathrm{x}}$. The $\mathrm{NO}_{\mathrm{x}}$ emission was found to be higher in the fuel blend of $\mathrm{Al}_{2} \mathrm{O}_{3}$ nanoparticles with a dosing level of $60 \mathrm{ppm}$ and lower than the B20 fuel blends. The most significant observation from this study was the engine combustion characteristics of TSME biodiesel with nano-additive demonstrated a remarkable improvement in exhaust emission as compared with B20 fuel blends.

Balasubramanian et al. [95] investigated the influence of $\mathrm{Al}_{2} \mathrm{O}_{3}$ nanoparticles in lemongrass oil biodiesel in a single-cylinder diesel engine. Different concentrations of nanoparticle additive (10, 20, and $30 \mathrm{ppm})$ were prepared and blended in the lemongrass oil biodiesel using an ultrasonicator. The best engine combustion performance and exhaust emissions were obtained under the dosing level of $20 \mathrm{ppm}$. For the same concentration level of $\mathrm{Al}_{2} \mathrm{O}_{3}$ nanoparticles, BTE was significantly improved by $11.5 \%$ as compared to the neat biodiesel. All emissions like $\mathrm{HC}, \mathrm{CO}, \mathrm{NO}_{\mathrm{x}}$, and smoke emission decreased by 40, 6, 31, and 39\%, respectively, as compared to the neat biodiesel. It is worth noting that the addition of $\mathrm{Al}_{2} \mathrm{O}_{3}$ nanoparticle in the lemongrass oil biodiesel improved engine combustion performance and reduced the harmful emission owing to the lower $\mathrm{NO}_{\mathrm{x}}$ emission and better combustion characteristics. 
Recently, Soudagar et al. [96] studied the potential use of $\mathrm{Al}_{2} \mathrm{O}_{3}$ nanoparticles as a fuel additive in Honge oil methyl ester (HOME20) biodiesel using different dosing levels of 20, 40, and $60 \mathrm{ppm}$. Based on their experiments, HOME20 fuel blend with a nanoparticle concentration level of $40 \mathrm{ppm}$ demonstrated a better engine combustion performance as compared to that of 20 and $60 \mathrm{ppm}$. For the dosing level of $40 \mathrm{ppm}$, BTE was found to be increased by $10.57 \%$ with a reduction in BSFC by $11.65 \%$. Furthermore, HC, CO, and smoke emission reduced by 26.72 , 48.43 , and $22.84 \%$, respectively. Conversely, the $\mathrm{NO}_{\mathrm{x}}$ emission increased by $11.27 \%$.

Table 3 summarized all of the above-mentioned experimental studies with some other undiscussed research works.

\section{$4.3 \mathrm{TiO}_{2}$}

Recently, Kumar et al. [103] investigated the influence of $\mathrm{TiO}_{2}$ nanoparticles on the performance, emission, and combustion characteristics of waste orange peel oil biodiesel with the dosing levels between 50 and $100 \mathrm{ppm}$. From the findings, the addition of nanoparticles with the dosing levels of 50 and $100 \mathrm{ppm}$ promoted the BTE for about $1.4 \%$ and $3.0 \%$, respectively, under maximum break power. However, pure diesel fuel showed maximum efficiency as compared with other testing samples. Also, they observed a significant reduction in smoke (24.2\%), $\mathrm{NO}_{\mathrm{x}}(9.7 \%)$, $\mathrm{CO}(18.4 \%)$, and $\mathrm{HC}(16.0 \%)$ for the sample with a dosing level of $100 \mathrm{ppm}$. Overall, orange oil biodiesel nano-emulsions (OOMEs) with $\mathrm{TiO}_{2}$ additive had better engine combustion performance as compared to neat biodiesel due to the improvement in the cylinder peak pressure, heat release rate, and combustion emissions. Furthermore, $\mathrm{TiO}_{2}$ nano-additives produce hydrogen from water, which can be attributed to its catalytic photoelectric effect $[104,105]$ and its ability to activate molecular bonds in the water-diesel emulsion [106].

In another recent study, Senthil et al. [107] evaluated the influence of two different dosing levels of $\mathrm{TiO}_{2}$ nanoparticles on the emission behaviour of diesel fuel in four-stroke, single-cylinder, $\mathrm{CI}$ engine. Under the dosing levels of 50 and $100 \mathrm{ppm}$, the addition of $\mathrm{TiO}_{2}$ nanoparticles improved the calorific values by 0.4 and $0.68 \%$, respectively. Likewise, the flashpoint of the biodiesel was also enhanced by 4.4 and $6.67 \%$ under the dosing level of 50 and $100 \mathrm{ppm}$, respectively. The addition of $\mathrm{TiO}_{2}$ to diesel fuel also caused a significant reduction in $\mathrm{CO}, \mathrm{HC}, \mathrm{NO}_{\mathrm{x}}$, and smoke emissions. These findings are consistent with the conclusions of previous studies $[52,62,108]$.

Karthikeyan and Viswanath [109] studied the effect of $\mathrm{TiO}_{2}$ nanoparticle on the combustion performance and emission characteristics of tamanu biodiesel in a two-cylinder diesel engine under a constant speed of 2,000 rpm. All emissions such as $\mathrm{HC}, \mathrm{CO}, \mathrm{NO}_{\mathrm{x}}$, and smoke were found to be lower. The concentration level of $100 \mathrm{ppm}$ produced the best combustion performance among other concentrations.

The influence of $\mathrm{TiO}_{2}$ nanoparticles in Calophyllum inophyllum biodiesel on the properties of fuel combustion features, engine performance, and emissions was studied by Praveen et al. [110]. They found that the kinematic viscosity, calorific value, and cetane number of the biodiesel increased with the addition of $\mathrm{TiO}_{2}$ nanoparticles as compared to the biodiesel. Higher cetane numbers improved the BTE owing to the higher oxygen quantity. The $\mathrm{NO}_{\mathrm{x}}$ and $\mathrm{HC}$ emissions reduced with the addition of nanoparticles as compared to the neat biodiesel. Similar findings were also reported by the previous researcher who studied the influence of $\mathrm{TiO}_{2}$ nanoparticles in Calophyllum inophyllum biodiesel [62].

Nanthagopal et al. [62] carried out the experiment using two different types of nanoparticles, namely, $\mathrm{TiO}_{2}$ and $\mathrm{ZnO} ; 50$ and $100 \mathrm{ppm}$ of each nanoparticle were blended into the biodiesel using an ultrasonicator. It was reported that a higher BTE was observed in the biodiesel with the addition of $\mathrm{TiO}_{2}$ and $\mathrm{ZnO}$ nanoparticles as compared to pure biodiesel. For biodiesel fuel doped with $100 \mathrm{ppm}$ of $\mathrm{TiO}_{2}$ nanoparticles, BTE increased by $17 \%$ as compared to that of pure biodiesel. Balasubramanian et al. [111] also observed a similar result when Mimusops elengi methyl ester (MEME) biodiesel was doped with $\mathrm{TiO}_{2}$ nanoparticle. This effect was due to the function of $\mathrm{TiO}_{2}$ nanoparticles as oxygen buffers and fuel boosters, which resulted in complete combustion and higher thermal efficiency.

El-Seesy et al. [112] carried out the experimental investigations to evaluate the combustion performance and emission characteristics of different fuel mixtures with varying percentages of $n$-hexane $(5,10$, and $15 \%$ by volume) and dosing levels of $\mathrm{TiO}_{2}$ nanoparticles ( 25 and $50 \mathrm{ppm}$ ). All of the mixtures were tested in a diesel engine under different engine loads and at a constant speed of 2,000 rpm. It was found out that by adding $\mathrm{TiO}_{2}$ nanoparticles in jojoba biodiesel-diesel- $n$-hexane mixture J30D5H (30\% JME + 65\% D100 + 5\% $n$-hexane), the BTE increased up to $15 \%$ as compared to the J30D5H fuel blend. A significant reduction in BSFC up to $12 \%$ was 
Table 3: Summary of $\mathrm{Al}_{2} \mathrm{O}_{3}$ nanoparticles studies as an additive in diesel/biodiesel fuel

\begin{tabular}{|c|c|c|c|c|}
\hline & Authors & Base fuel & Nanoparticles & Mass fraction of nanoparticles \\
\hline 1 & $\begin{array}{l}\text { Sathiamurthi et al. [88] } \\
\text { Engine performance: Higher BTE } \\
\text { Harmful emission: Reduction in }\end{array}$ & $\begin{array}{l}\text { Diesel fuel } \\
x_{x} \text { and UBHC }\end{array}$ & $\mathrm{Al}_{2} \mathrm{O}_{3}$ & 0.5 and $1 \mathrm{~g} / \mathrm{L}$ \\
\hline 2 & $\begin{array}{l}\text { Venkatesan and Kadiresh [89] } \\
\text { Engine performance: Higher BTE } \\
\text { Harmful emission: Reduction in }\end{array}$ & $\begin{array}{l}\text { Diesel fuel } \\
x \text { and UBHC }\end{array}$ & $\mathrm{Al}_{2} \mathrm{O}_{3}$ & 1 and $1.5 \mathrm{~g} / \mathrm{L}$ \\
\hline 3 & $\begin{array}{l}\text { Basha }[90] \\
\text { Engine performance: Higher BTE } \\
\text { Harmful emission: Reduction in }\end{array}$ & $\begin{array}{l}\text { Diesel fuel } \\
x, \mathrm{CO}, \text { and } \mathrm{sn}\end{array}$ & $\mathrm{Al}_{2} \mathrm{O}_{3}$ & 25,50 , and $100 \mathrm{ppm}$ \\
\hline 4 & $\begin{array}{l}\text { Gumus et al. [50] } \\
\text { Engine performance: Lower BSFC } \\
\text { Harmful emission: } \mathrm{CO} \text {, UHC, and }\end{array}$ & $\begin{array}{l}\text { Diesel fuel } \\
\mathrm{Al}_{2} \mathrm{O}_{3} \text { and } \mathrm{CuC} \\
\mathrm{O}_{\mathrm{x}} \text { reduced } \mathrm{b}\end{array}$ & $\begin{array}{l}\mathrm{Al}_{2} \mathrm{O}_{3} \text { and } \mathrm{CuO} \\
2 \% \text {, respectively } \\
\mathrm{O}_{3} \text { and } 5,8 \text {, and } 2\end{array}$ & $\begin{array}{l}50 \mathrm{ppm} \\
\text { tively, for } \mathrm{CuO}\end{array}$ \\
\hline 5 & Ang et al. [49] & Diesel fuel & $\mathrm{Al}_{2} \mathrm{O}_{3}, \mathrm{CNT}, \mathrm{SiO}_{2}$ & 25,50 , and $100 \mathrm{ppm}$ \\
\hline
\end{tabular}
by $4.48 \%$ with an increase in $\mathrm{CO}, \mathrm{CO}_{2}$, and $\mathrm{HC}$ emissions
Raju et al. [94]
Tamarind seed methyl ester
$\mathrm{Al}_{2} \mathrm{O}_{3}$ and CNT
30 and $60 \mathrm{ppm}$

Engine performance: Lower BSFC and higher BTE

Harmful emission: A significant reduction in smoke, $\mathrm{HC}$, and $\mathrm{CO}$ emissions. $\mathrm{A}$ higher $\mathrm{NO}_{\mathrm{x}}$ for $\mathrm{Al}_{2} \mathrm{O}_{3}$ with $60 \mathrm{ppm}$

7 Balasubramanian et al. [95] Lemongrass oil biodiesel $\quad \mathrm{Al}_{2} \mathrm{O}_{3} \quad 10,20$, and 30 ppm

Engine performance: Higher BTE and lower BSFC

Harmful emission: $\mathrm{HC}$ and $\mathrm{CO}$ emissions reduced by $40 \%$ and $6 \% . \mathrm{NO}_{\mathrm{x}}$ and smoke emissions decreased by $31 \%$ and $39 \%$ as compared to pure biodiesel

8 Soudagar et al. [96]

Engine performance: BTE improved by $10.57 \%$, while BSFC decreased by $11.65 \%$

Harmful emission: $\mathrm{CO}$ emission reduced by 42 and $3 \%$ as compared to $\mathrm{B} 5 \mathrm{~W} 7$ and $\mathrm{B} 5$, respectively

Calophyllum inophyllum biodiesel $\mathrm{Al}_{2} \mathrm{O}_{3}$

$40 \mathrm{ppm}$

Engine performance: Higher BTE and lower BSFC with an increase in brake power for all the fuel samples

Harmful emission: $\mathrm{CO}, \mathrm{HC}, \mathrm{NO}_{x}$, and smoke emissions reduced by $6.09,12.24 \%, 7.76$, and $6.2 \%$, respectively

Rubber seed oil

$\mathrm{Al}_{2} \mathrm{O}_{3}$

10,15 , and $20 \mathrm{ppm}$

Engine performance: Maximum BTE (10 ppm) was achieved under full load. For the case of 15 and 20 ppm, BTE decreased. BSFC decreased with a higher engine load

Harmful emission: $20 \mathrm{ppm}$ had a higher $\mathrm{CO}$ emission (0.35\%). $\mathrm{NO}_{\mathrm{x}}$ emission for $10 \mathrm{ppm}$ was higher when compared to the other samples

Soybean biodiesel

$\mathrm{Al}_{2} \mathrm{O}_{3}$

$100 \mathrm{ppm}$

Engine performance: Higher BTE and lower BSFC under a higher engine load

Harmful emission: Remarkable reduction in harmful emissions. Observed a small increase in $\mathrm{NO}_{\mathrm{x}}$ emission with nano-additive

12 Prabu and Anand [85] Jatropha biodiese

Jatropha biodiesel $\quad \mathrm{Al}_{2} \mathrm{O}_{3}$ and $\mathrm{CeO}_{2}$

10,30 , and $60 \mathrm{ppm}$

Engine performance: BTE and BSFC were almost similar to neat diesel

Harmful emission: Lower $\mathrm{NO}_{\mathrm{x}}, \mathrm{CO}, \mathrm{UHC}$, and smoke opacity

13 Ramesh et al. [99]

Engine performance: Higher BTE

Poultry litter oil methyl ester

$\mathrm{Al}_{2} \mathrm{O}_{3}$

30 ppm

Harmful emission: Lower $\mathrm{CO}, \mathrm{UBHC}$, and $\mathrm{NO}_{x}$ emissions

14 Sivakumar [100] Pongamia methyleste

Engine performance: $100 \mathrm{ppm}$ exhibited a better BTE and BSFC under maximum load

Harmful emission: Lower $\mathrm{HC}, \mathrm{CO}$, and smoke emissions for both ppm

15 Syed Aalam et al. [101]

Zizipus jujube methyl ester

$\mathrm{Al}_{2} \mathrm{O}_{3}$

25 and $50 \mathrm{ppm}$

blended fuel

Engine performance: BSFC values of $25 \mathrm{ppm}$ were nearly the same as pure diesel fuel. BSFC value decreased by about $6 \%$ for $50 \mathrm{ppm}$. BTE increased; $50 \mathrm{ppm}$ showed a maximum increase (2.5\%) when compared to $25 \mathrm{ppm}$

Harmful emission: Lower $\mathrm{HC}, \mathrm{CO}$, and smoke emissions with a slight increase in $\mathrm{NO}_{\mathrm{x}}$ emission

Mehta et al. [102] Petrodiesel $\mathrm{Al}_{2} \mathrm{O}_{3}, \mathrm{FeO}_{2}$, and $\mathrm{B}_{2} \mathrm{O}_{3}-$
Engine performance: Reduced by $7 \%$ in $\mathrm{BSFC}$ with $\mathrm{Al}_{2} \mathrm{O}_{3}$. Increase in $\mathrm{BTE}$ by 9,4 , and $2 \%$ for $\mathrm{Al}_{2} \mathrm{O}_{3}, \mathrm{FeO}_{2}$, and $\mathrm{B}_{2} \mathrm{O}_{3}$, respectively, as
compared to diesel under higher loads
Harmful emission: $\mathrm{CO}$ emission reduced by $25-40 \%$ in $\mathrm{CO}$ (vol\%), $\mathrm{HC}$ emission reduced by 8 and $4 \%$ for $\mathrm{Al}_{2} \mathrm{O}_{3}$ and FeO $\mathrm{F}_{2}$, respectively.
$\mathrm{NO}_{\mathrm{x}}$ emission increased by 5 and $3 \%$ for $\mathrm{Al}_{2} \mathrm{O}_{3}$ and $\mathrm{FeO}_{2}$, respectively


also observed in the J30D5H nanoparticle's fuel blend. This can be credited to the beneficial presence of the nanoparticles which enhanced the combustion and mixing process. Furthermore, the $\mathrm{NO}_{\mathrm{x}}$ emission was observed to be higher when the nanoparticles were blended with J30D5H biodiesel. Surprisingly, the addition of $n$-hexane and $n$ pentane enhanced the BTE and reduced the harmful emissions [113].

Table 4 summarizes the effect of $\mathrm{TiO}_{2}$ nanoparticles on the performance, combustion, and emission characteristics

Table 4: Summary of $\mathrm{TiO}_{2}$ nanoparticles as an additive in diesel/biodiesel fuel

\begin{tabular}{lllcc}
\hline & Authors & Base fuel & Nanoparticles & Mass fraction of nanoparticles \\
\hline 1 & Kumar et al. [103] & OOME biodiesel & $\mathrm{TiO}_{2}$ & 50 and $100 \mathrm{ppm}$ \\
& Engine performance: For 50 and $100 \mathrm{ppm}$, BTE increased by 1.6 and $3.0 \%$, respectively, under maximum load condition. Lower BSFC \\
& Harmful emission: A reduction in $\mathrm{Co}, \mathrm{HC}$, and smoke emission. $\mathrm{NO}_{\mathrm{x}}$ showed an increasing trend with the addition of nanoparticle \\
2 & Senthil et al. [107] & Diesel fuel & $\mathrm{TiO}_{2}$ & 50 and $100 \mathrm{ppm}$
\end{tabular}

Engine performance: -

Harmful emission: For 50 and 100 ppm, $\mathrm{HC}$ emissions reduced by 1.7 and $2.3 \%$, respectively. Likewise, for 50 and 100 ppm, $\mathrm{NO}_{\mathrm{x}}$ emissions decreased by 3.7 and $4.1 \%$, respectively. $\mathrm{CO}$ and smoke opacity also decreased

3 Yuvarajan et al. [108] $\quad$ Mustard oil methyl ester $\quad \mathrm{TiO}_{2} \quad 100$ and $200 \mathrm{ppm}$

Engine performance: -

Harmful emission: Lower $\mathrm{HC}, \mathrm{CO}$, and smoke emissions. $\mathrm{NO}_{\mathrm{x}}$ emissions were higher than diesel under all load conditions

4 Karthikeyan and Viswanath [109] Tamanu biodiesel $\quad \mathrm{TiO}_{2} \quad$ 25, 50, 75, and $100 \mathrm{ppm}$

Engine performance: -

Harmful emission: $\mathrm{CO}, \mathrm{NO}_{\mathrm{x}}$, and smoke emissions reduced

5 Anchupogu et al. [110] Calophyllum inophyllum biodiesel $\mathrm{TiO}_{2} \quad 40 \mathrm{ppm}$

Engine performance: Higher BTE and heat release

Harmful emission: $\mathrm{CO}$ and $\mathrm{HC}$ decreased by 23 and $12 \%$, respectively. Smoke emission also decreased

6 Nanthagopal et al. [62] Calophyllum inophyllum biodiesel $\mathrm{TiO}_{2}$ and $\mathrm{ZnO} \quad 50$ and $100 \mathrm{ppm}$

Engine performance: Higher BTE with increasing engine load. Lower BSFC

Harmful emission: Lower $\mathrm{HC}, \mathrm{CO}, \mathrm{CO}_{2}, \mathrm{NO}_{x}$, and smoke emissions

7 Balasubramanian et al. [111] $\quad$ MEME biodiesel $\quad \mathrm{TiO}_{2} \quad$ 25, 50, 75, and 100 ppm

Engine performance: Higher BTE in 25 ppm

Harmful emission: Lower $\mathrm{HC}$ and smoke emissions. $\mathrm{NO}_{\mathrm{x}}$ emission rose marginally

8 Manigandan et al. [114] Corn methyl ester biodiesel $\quad \mathrm{TiO}_{2} \quad 100,200$, and 300 ppm

Engine performance: Higher BP and BTE. Lower BSFC

Harmful emission: Lower $\mathrm{CO}, \mathrm{HC}$, and smoke emissions. Lower $\mathrm{NO}_{\mathrm{x}}$ and particulate emission

9 Sundararajan and Anand [115] Plastic diesel oil $\quad \mathrm{TiO}_{2} \quad 20 \mathrm{ppm}$

Engine performance: Higher BTE and lower BSFC. Improved combustion efficiency

Harmful emission: Lower $\mathrm{NO}_{\mathrm{x}}$ emissions

10 El-Seesy et al. [112] J30D5H blended biodiesel $\quad \mathrm{TiO}_{2} \quad 25$ and $50 \mathrm{ppm}$

Engine performance: BSFC reduced by $12 \%$, while BTE increased by $15 \%$

Harmful emission: $\mathrm{CO}$ and UHC emissions decreased by 20 and $50 \%$, respectively. However, there was an increase in $\mathrm{NO}_{\mathrm{x}}$ by $15 \%$

11 Örs et al. [116] Waste cooking oil biodiesel

Engine performance: Increased the maximum cylinder pressure and heat release rate values. Higher BTE. Lower BSFC

Harmful emission: Lower $\mathrm{CO}, \mathrm{HC}$, and smoke opacity emission. Higher $\mathrm{CO}_{2}$ and $\mathrm{NO}$ emissions

12 Kandasamy and Jabaraj [117] Cottonseed oil methyl ester $\quad \mathrm{TiO}_{2} \quad 20$ and $40 \mathrm{ppm}$

Engine performance: Improved combustion efficiency

Harmful emission: Lower exhaust gas emissions

13 Nithya et al. [64]

Canola biodiesel

$\mathrm{TiO}_{2}$

$300 \mathrm{ppm}$

Engine performance: -

Harmful emission: $\mathrm{NO}_{x}$ reduced by $5 \%$. $\mathrm{CO}, \mathrm{HC}$, and smoke opacity emissions reduced to 32,30 , and $52 \%$, respectively

14 Pandian et al. [118] $\quad$ Mustard oil biodiesel $\quad \mathrm{TiO}_{2} \quad 100,200$, and 300 ppm

Engine performance: -

Harmful emission: Significant reduction in $\mathrm{HC}, \mathrm{CO}, \mathrm{NO}_{x}$, and smoke emission. The dosing level of $300 \mathrm{ppm}$ produced the best performance

15 Prabhu et al. [119] $\quad$ Neem oil biodiesel

$\mathrm{TiO}_{2} \quad 250$ and $500 \mathrm{ppm}$

Harmful emission: Lower $\mathrm{CO}, \mathrm{HC}$, and smoke emissions. However, a slight increase was observed in $\mathrm{NO}_{\mathrm{x}}$ for the dosing level of $250 \mathrm{ppm}$ as compared with B20 and $500 \mathrm{ppm}$. Overall, $250 \mathrm{ppm}$ produced the best performance 
of diesel/biodiesel fuel with some other undiscussed research works.

\subsection{Other metal oxides nanoparticles}

The effects of other metal oxide nanoparticles as an additive on the performance, combustion, and emission characteristics in the ICE are presented in this section and listed in Table 5. Recently, Mehregan and Moghiman [120] added 25 and $50 \mathrm{ppm} \mathrm{Mn}_{2} \mathrm{O}_{3}$ and $\mathrm{Co}_{3} \mathrm{O}_{4}$, respectively, into the waste frying oil biodiesel which contained $20 \%$ wastes frying oil biodiesel and $80 \%$ ultralow sulphur diesel and urea-selective catalytic reduction (SCR) system. A reduction in $\mathrm{NO}_{\mathrm{x}}$ emissions was reported from the nanoparticle fuel blend. $\mathrm{Co}_{3} \mathrm{O}_{4}$ with the dosing level of $50 \mathrm{ppm}$ demonstrated remarkable thermal properties.

Recently Vedagiri et al. [121] investigated the influence of different open burning chamber geometries on the performance, combustion, and emission of $\mathrm{CI}$ engines by adding $\mathrm{ZnO}$ nanoparticles into grapeseed oil methyl ester (GOME) biodiesel as a fuel additive. With the addition of ZnO nanoparticles, the BTE was found to be increased from 28.17 to $29.3 \%$, and BSFC decreased slightly from 0.3258 to $0.3128 \mathrm{~kg} / \mathrm{kWh}$. A significant reduction in $\mathrm{NO}_{\mathrm{x}}, \mathrm{HC}$, and $\mathrm{CO}$ emissions was also observed. Overall, the toroidal combustion chamber produced a better combustion performance as compared to the other combustion chambers.

Amirabedia et al. [122] and Amirabedi et al. [123] blended two different types of nanoparticles into the spark-ignition (SI) gasoline along with ethanol. An ultrasonicator was used to blend $10 \mathrm{ppm} \mathrm{Mn}_{2} \mathrm{O}_{3}$ and $20 \mathrm{ppm}$ $\mathrm{Co}_{3} \mathrm{O}_{4}$ nanoparticles into the gasoline-ethanol fuel. From the results, it was observed that higher $\mathrm{BP}$ values were obtained with increasing dosing levels of nanoparticles. For the dosing levels of 10 and $20 \mathrm{ppm} \mathrm{Mn}_{2} \mathrm{O}_{3}$, the $\mathrm{BP}$ values increased by 14.38 and $19.56 \%$, respectively. Meanwhile, the $\mathrm{BP}$ values of 10 and 20 ppm $\mathrm{Co}_{3} \mathrm{O}_{4}$ increased by 7.96 and $11.5 \%$, respectively. Furthermore, a reduction in $\mathrm{CO}$ and UHC emissions was observed with an increase in $\mathrm{CO}_{2}$ when ethanol was mixed with the nanoparticles. From the results, the gasoline-ethanol fuel blend with $20 \mathrm{ppm} \mathrm{Mn}_{2} \mathrm{O}_{3}$ nanoparticles produced the best combustion and emission performances. These findings are consistent with the previous study by Ananda et al. [75], where the addition of ethanol and nanoparticle additives in gasoline fuel improved engine performance and exhaust emissions.

Devarajan et al. [53] investigated the effect of different mass fractions of AgO nano-additive (5 and $10 \mathrm{ppm}$ ) and particle sizes (10 and $20 \mathrm{~nm}$ ) on the performance, emission, and combustion behaviour of palm stearin biodiesel. At peak load conditions, a higher BTE value and a low BSFC emission were obtained from the biodiesel fuel blend with nanoparticles with a particle size of $20 \mathrm{~nm}$ and a concentration level of $10 \mathrm{ppm}$. The addition of AgO nanoparticles to the biodiesel reduced the harmful emission. It was observed that the biodiesel fuel with $10 \mathrm{ppm}$ of $20 \mathrm{~nm}$ AgO nanoparticles exhibited the best engine performance. As compared to biodiesel, the in-cylinder pressure reduced by $2.2 \%$ and the net heat release rate value improved by $4.7 \%$.

Tamilvanan et al. [124] investigated the performance, combustion, and emission behaviours of Calophyllum inophyllum seed oil (CISO) biodiesel with 30 ppm Cu additives in a single-cylinder diesel engine under varying loads. At all loads, a higher BTE value was obtained from the biodiesel blend with $\mathrm{Cu}$ as compared to that without additive. However, the BTE value was slightly lower than diesel. The reduction in BTE value in biodiesel can be ascribed to the lower heat of combustion. The addition of $\mathrm{Cu}$ nanoparticles in biodiesel fuel blends increased the combustion properties of the engine and reduced the emissions significantly.

Venu and Appavu [125] added Zr nanoparticles into the jatropha biodiesel for the CI engine. It was pointed out that the BSFC value of jatropha biodiesel with $\mathrm{Zr}$ nanoparticles was the lowest, and the BTE value was the highest as compared to diesel and biodiesel without $\mathrm{Zr}$ nanoparticles. A significant reduction in $\mathrm{HC}, \mathrm{CO}$, and smoke emissions was observed with a slight increase in $\mathrm{NO}_{\mathrm{x}}$ and $\mathrm{CO}_{2}$ emissions. Some similarities can be found between this work and the work of Yogaraj et al. [126] who used $\mathrm{Ag}-\mathrm{TiO}_{2}$ nanoparticle as the fuel additive. By adding the additives, incomplete combustion led to lower $\mathrm{BSFC}, \mathrm{CO}_{2}$, and $\mathrm{HC}$ emissions. However, a higher $\mathrm{NO}_{\mathrm{x}}$ emission was observed in all cases.

The effect of adding $\mathrm{CuO}$ nano-additives to the Neochloris oleoabundans methyl ester diesel (NOMED) blend was investigated by Kalaimurugan et al. [127]. A month later, the same authors published the work using $\mathrm{RuO}_{2}$ nanoparticles, whose fuel properties were very similar to that of $\mathrm{CuO}$ nanoparticles [128] except for the difference in the cetane index value. The cetane index of $\mathrm{RuO}_{2}$ and $\mathrm{CuO}$ was 52 and 55, respectively. The fuel test was performed using different concentration levels between 25 and 100 ppm under varying load conditions. From the results, both 100 ppm nanoparticles promoted a lower BTE, BSFC, and exhaust emissions.

Srinidhi et al. [129] studied the CI performance of $\mathrm{NiO}$ nanoparticles in Azadirachta indica biodiesel at different injection timings and dosing levels from 25 to $100 \mathrm{ppm}$. 
Table 5: Summary of other metal oxides nanoparticles as an additive in diesel/biodiesel fuel

\begin{tabular}{|c|c|c|c|c|}
\hline & Authors & Base fuel & Nanoparticles & Mass fraction of nanoparticles \\
\hline 1 & $\begin{array}{l}\text { Mehregan and Moghiman }[120] \\
\text { Engine performance: }- \\
\text { Harmful emission: Reduced } \mathrm{NO}_{\mathrm{x}}\end{array}$ & $\begin{array}{l}\text { Waste frying oil biodiesel } \\
\text { emissions. } \mathrm{Co}_{3} \mathrm{O}_{4} \text { with } 50 \mathrm{pp}\end{array}$ & $\begin{array}{l}\mathrm{Mn}_{2} \mathrm{O}_{3} \text { and } \mathrm{CO}_{3} \mathrm{O}_{4} \\
\text { better results }\end{array}$ & 25 and $50 \mathrm{ppm}$ \\
\hline 2 & Vedagiri et al. [121] & GOME biodiesel & $\mathrm{ZnO}$ & $100 \mathrm{ppm}$ \\
\hline & $\begin{array}{l}\text { Engine performance: Higher BTE } \\
\text { Harmful emission: Lower smoke }\end{array}$ & $\begin{array}{l}\text { and lower } \mathrm{BSFC} \\
\text { emissions, } \mathrm{HC}, \mathrm{CO} \text {, and } \mathrm{NO}_{\mathrm{x}}\end{array}$ & & \\
\hline 3 & Amirabedia et al. [122] & gasoline fuelled & $\mathrm{Mn}_{2} \mathrm{O}_{3}$ and $\mathrm{Co}_{3} \mathrm{O}_{4}$ & 10 and $20 \mathrm{ppm}$ \\
\hline
\end{tabular}

Engine performance: Higher BTE and BP. Lower BSFC

Harmful emission: Lower $\mathrm{CO}$, UHC, and $\mathrm{NO}_{x}$ emission. Higher $\mathrm{CO}_{2}$ emission. Gasoline $-10 \%$ of ethanol $-20 \mathrm{ppm} \mathrm{Mn}_{2} \mathrm{O}_{3}$ produced better results

4 Amirabedi et al. [123] Gasoline fuelled $\quad \mathrm{Mn}_{2} \mathrm{O}_{3} \quad 10$ and $20 \mathrm{ppm}$

Engine performance: Higher BTE and BP. Lower BSFC reduced

Harmful emission: Lower $\mathrm{CO}, \mathrm{UHC}$, and $\mathrm{NO}_{\mathrm{x}}$ emission. Higher $\mathrm{CO}_{2}$ emission

5 Devarajan et al. [53] Palm stearin biodiesel $\quad$ AgO $\quad 5$ and 10 ppm

Engine performance: Higher BTE and lower BSFC

Harmful emission: $\mathrm{HC}$ and $\mathrm{CO}$ emissions were reduced by up to 8.8 and $11.9 \%$, respectively. $\mathrm{NO}_{\mathrm{x}}$ and smoke emissions were also reduced

6 Tamilvanan et al. [124] CISO biodiesel $\quad$ Cu ppm

Engine performance: Higher BTE and lower BSFC

Harmful emission: $\mathrm{HC}, \mathrm{NO}_{\mathrm{x}}$ and $\mathrm{O}_{2}$ emissions reduced. However, $\mathrm{CO}_{2}$ emission increased

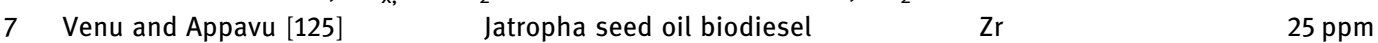

Engine performance: Lower BSFC and higher BTE

Harmful emission: Reduction in $\mathrm{HC}, \mathrm{CO}$ emissions, and smoke opacity. But a slight increase in $\mathrm{NO}_{\mathrm{x}}$ and $\mathrm{CO}_{2}$ emissions

8 Yogaraj et al. [126] Jatropha biodiesel $\quad \mathrm{Ag}_{-} \mathrm{TiO}_{2} \quad 30 \mathrm{ppm}$

Engine performance: A marginal increase of $3.3 \%$ at maximum load in BTE. Higher BP and lower BSFC

Harmful emission: Decreased UBHC by $12 \%$, CO by $14 \%$ at a maximum load

9 Kalaimurugan et al. [127] NOMAD blended $\quad \mathrm{CuO}_{2} \quad$ 25, 50, 75, and 100 ppm

Engine performance: Higher BTE and EGT. Lower BSFC

Harmful emission: Lower $\mathrm{CO}, \mathrm{HC}$, and smoke emissions. Higher $\mathrm{NO}_{\mathrm{x}}$ emission. The concentration level of 100 ppm produced better results

10 Kalaimurugan et al. [128] NOMAD blended $\quad \mathrm{RuO}_{2} \quad 25,50,75$, and 100 ppm

Engine performance: Lower BSFC. Higher BTE

Harmful emission: Emits less $\mathrm{CO}$ and $\mathrm{HC}$ emissions. Unfortunately, a higher amount of $\mathrm{NO}_{\mathrm{x}}$ emissions was observed compared to $\mathrm{B} 20$

11 Srinidhi et al. [129] Azadirachta indica biodiesel NiO 25, 50, 75, and 100 ppm

Engine performance: Higher BTE. Lower BSFC

Harmful emission: Lower $\mathrm{HC}$ and $\mathrm{CO}$ emissions. Higher $\mathrm{NO}_{\mathrm{x}}$ emission

12 Perumal and Ilangkumaran [54] Pongamia methyl ester biodiesel $\quad \mathrm{CuO}_{2} \quad 50$ and $100 \mathrm{ppm}$

Engine performance: Higher BTE. Lower BSFC

Harmful emission: Lower $\mathrm{CO}, \mathrm{HC}, \mathrm{NO}_{x}$, and smoke emissions

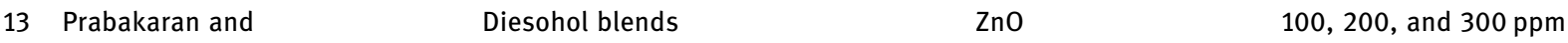

Vijayabalan [130]

Engine performance: Higher BTE

Harmful emission: Lower $\mathrm{CO}, \mathrm{HC}$, and $\mathrm{NO}_{x}$ emissions

14 Prabakaran and Udhoji [131] Diesel-biodiesel-ethanol blends $\quad$ ZnO $250 \mathrm{ppm}$

Engine performance: Higher BTE. Lower BSFC

Harmful emission: Lower $\mathrm{CO}, \mathrm{NO}_{\mathrm{x}}$, and smoke emissions. A slight reduction in $\mathrm{HC}$ emission

15 Gangwar et al. [132] Diesel fuel Cu-Zn alloy $\quad 100$ and 200 ppm

Engine performance: Higher BTE. Lower BSFC

Harmful emission: Lower $\mathrm{CO}, \mathrm{UBHC}, \mathrm{CO}_{2}$, and $\mathrm{NO}_{\mathrm{x}}$ emissions under full load. $200 \mathrm{ppm}$ of nanoparticles produced better results

Three types of injection timing were prepared including 23,19 , and $27^{\circ}$ bTDC (before top dead centre). As a result, the increase in fuel injection timing and the presence of nanoparticles improved the overall engine performance and reduced the release of harmful emissions from the engine.

The blending of $\mathrm{CuO}$ nanoparticles in pongamia biodiesel fuel has undergone different engine operation 
characteristics in a single-stroke four-cylinder engine. By using a 10-mL Span80 surfactant and an ultrasonicator, 50 and $100 \mathrm{ppm} \mathrm{CuO}$ nanoparticles were mixed with the pongamia biodiesel to obtain different biodiesel blends. For the dosing level of $100 \mathrm{ppm}$, the engine performance and maximum emission reduction enhanced [54]. Higher cetane number and oxygen content improved the BTE value with a reduction in $\mathrm{HC}$, $\mathrm{CO}$, and smoke emissions [130-133].

\subsection{Non-metal oxide nanoparticles}

Aside from metal oxide nanoparticles, non-metal oxide nanoparticles also demonstrated excellent properties [133-148] in enhancing the performance, combustion, and emission characteristics of an ICE. Table 6 summarized all of the recent findings from previous studies.

In one of the most recent works, Soudagar et al. [134] investigated the influences of GO nanoparticles on the performance and emissions of a $\mathrm{CI}$ engine fuelled with dairy scum oil (DSOME) biodiesel using dosing levels of 20, 40, and $60 \mathrm{ppm}$ under constant speed and varying $\mathrm{BP}$ and load conditions. GO is known as a nanoparticle with ultrahigh strength, good hydrophilicity, and dispersibility [147]. From the results, it was revealed that the net heat release and BTE values improved with an increasing amount of GO nano-additives in the fuel blends. Furthermore, the addition of GO nanoparticles in the biodiesel enhanced engine performance and emission characteristics. El-Seesy et al. $[139,143]$ showed similar results on the performance and emissions of CI engine fuelled by Jatropha methyl ester biodiesel nanoparticle blend with GO nanoparticles. The addition of GO nanoparticles in the base fuel enhanced the combustion characteristics and reduced the exhaust emissions including $\mathrm{CO}, \mathrm{NO}_{\mathrm{x}}, \mathrm{SO}_{2}$, $\mathrm{CO}_{2}$, and smoke. It also improved the overall engine performance parameters such as BTE and BP with a reduction in the BSFC values (as shown in Figure 4). Such superior performance can be attributed to the high surface area to volume ratio of the mixture, which promoted a better fuelair mixing pattern during the combustion process.

Mei et al. [135] compared the combustion and emission of a standard rail diesel blended with non-metallic and metallic oxide nanoparticles. $\mathrm{CNT}$ and $\mathrm{MoO}_{3}$ nanoparticles were used as the fuel additives in the study. All CNT diesel blend and $\mathrm{MoO}_{3}$ diesel blend were found to achieve high efficiencies in fuel economy, combustion, and emissions as compared to pure diesel. This is because CNT nanoparticles possessed excellent thermal conductivity and surface deficits [148], while $\mathrm{MoO}_{3}$ owned superior catalytic oxidation performance. Based on the findings, it was observed that CNT offered superior combustion efficiency and better ability to reduce exhaust emissions as compared to $\mathrm{MoO}_{3}$ diesel blend.

Sivathanu and Anantham [137] studied the capability of MWCNT as a fuel additive in improving the performance, emission, and combustion behaviour of diesel engine fuelled with waste fishing oil. As compared with neat biodiesel fuel, the addition of MWCNT in biodiesel promoted a lower exhaust emission and a shorter ignition delay. Under $100 \%$ load, BTE increased by $3.83 \%$. On the contrary, the BSFC value by $3.87 \%$ with the presence of MWCNT. The findings also showed a substantial decrease in engine exhaust emissions including $\mathrm{CO}, \mathrm{UHC}$, NO, and smoke by $25,9.09,5.25$, and $14.81 \%$, respectively. At the same time, a slight increase by $17.39 \%$ in $\mathrm{CO}_{2}$ emission was also observed. These results are in good agreement with the findings of Sulochana and Bhatti [138] and El-Seesy et al. [146].

Sandeep et al. [140] studied the ability of CNT as a fuel additive in improving diesel engine performance using HOME. As compared to pure biodiesel at full load, the addition of CNT enhanced the BTE value by $2.24 \%$ and reduced the BSFC by $20.68 \%$. Besides, a remarkable reduction in harmful emissions was also observed.

Basha [141] investigated the combustion performance of pristine biodiesel and biodiesel emulsions blended with CNT and DEE in IC engines. The experimental results showed that the biodiesel emulsion fuel with CNT and DEE showed better efficiency, emission, and combustion characteristics in contrast to pure diesel and biodiesel. The BTE value of CNT + DEE fuel increased by $3.5 \%$. Besides, $\mathrm{NO}_{\mathrm{x}}$ and smoke emissions were reduced by $445 \mathrm{ppm}$ and $35 \%$, respectively, when compared with the pure diesel. The study also found out that the addition of $50 \mathrm{ppm}$ of CNT and $50 \mathrm{~mL}$ of DEE to emulsified biodiesel fuel could reduce the delay in ignition. This is owing to higher cetane number of DEE.

Hosseini et al. [142] investigated the performance and emission characteristics of mixed diesel B5 and B10 with the addition of CNT. Different concentrations of 30, 60, and $90 \mathrm{ppm}$ CNT nanoparticles were added into diesel. The findings revealed that the power, BTE, and EGT of all CNT fuel blends improved by 3.67, 8.12, and 5.57\%, respectively. At the same time, biodiesel blends with CNT nanoparticle additive exhibited a significant reduction in BSFC. In terms of emission characteristics, it was found out that the CO, UHC, and soot emission of the diesel biodiesel mixture reduced with an increase in $\mathrm{NO}_{\mathrm{x}}$ emission. 
Table 6: Summary of non-metal oxides nanoparticles as an additive in diesel/biodiesel fuel

\begin{tabular}{|c|c|c|c|c|}
\hline \multicolumn{2}{|c|}{ Authors } & \multirow{2}{*}{$\begin{array}{l}\text { Base fuel } \\
\text { DSOME biodiesel }\end{array}$} & \multirow{2}{*}{$\begin{array}{l}\text { Nanoparticles } \\
\text { GO }\end{array}$} & \multirow{2}{*}{$\begin{array}{l}\text { Mass fraction of nanoparticles } \\
20,40 \text {, and } 60 \mathrm{ppm}\end{array}$} \\
\hline 1 & Soudagar et al. [134] & & & \\
\hline & \multicolumn{4}{|c|}{ Engine performance: BTE improved by $11.56 \%$. BSFC reduced by $8.34 \%$} \\
\hline & \multicolumn{4}{|c|}{ Harmful emission: UBHC, smoke, $\mathrm{CO}_{2}, \mathrm{NO}_{x}$ reduced by $21.68,24.88,38.662$, and $5.62 \%$, respectively } \\
\hline \multirow[t]{3}{*}{2} & Mei et al. [135] & Neat diesel & CNT and $\mathrm{MoO}_{3}$ & 50 and $100 \mathrm{ppm}$ \\
\hline & \multicolumn{4}{|c|}{ Engine performance: Higher BTE. Lower BSFC } \\
\hline & \multicolumn{4}{|c|}{ Harmful emission: All the emissions were decreased. CNT produced better results as compared to $\mathrm{MoO}_{3}$} \\
\hline \multirow[t]{3}{*}{3} & Hosseinzadeh et al. [136] & Waste cooking oil & Carbon & 38,75 , and $150 \mu \mathrm{M}$ \\
\hline & \multicolumn{4}{|c|}{ Engine performance: Higher BP and BTE. Lower BSFC } \\
\hline & \multicolumn{4}{|c|}{ Harmful emission: $\mathrm{HC}, \mathrm{CO}$, and $\mathrm{NO}_{\mathrm{x}}$ emission reduced under full load } \\
\hline \multirow[t]{3}{*}{4} & Sivathanu and Anantham [137] & Waste fishing net oil & MWCNT & - \\
\hline & \multicolumn{4}{|c|}{ Engine performance: BTE increased by $3.83 \%$ and BSFC decreased by $3.87 \%$} \\
\hline & \multicolumn{4}{|c|}{ Harmful emission: Reduction in $\mathrm{CO}, \mathrm{UHC}, \mathrm{NO}$, and smoke by $25,9.09,5.25$, and $14.81 \%$. A slight increase in $\mathrm{CO}_{2}$ emission by $17.39 \%$} \\
\hline \multirow[t]{3}{*}{5} & Sulochana and Bhatti [138] & Waste fry oil methyl ester & MWCNT & 25 and $50 \mathrm{ppm}$ \\
\hline & \multicolumn{4}{|l|}{ Engine performance: Higher BTE } \\
\hline & \multicolumn{4}{|c|}{ Harmful emission: Lower $\mathrm{CO}, \mathrm{HC}$, and $\mathrm{NO}_{\mathrm{x}}$ emissions } \\
\hline \multirow[t]{3}{*}{6} & El-Seesy et al. [139] & Jatropha methyl ester & GO, GNP and MWCNT & $50 \mathrm{ppm}$ \\
\hline & \multicolumn{4}{|c|}{ Engine performance: BTE increased by $25 \%$ and BSFC decreased by $35 \%$} \\
\hline & \multicolumn{4}{|c|}{ Harmful emission: Reduction in $\mathrm{CO}, \mathrm{UHC}, \mathrm{NO}$, and smoke emissions by $55,50,45$, and $14.81 \%$, respectively } \\
\hline \multirow[t]{3}{*}{7} & Sandeep et al. [140] & Honge oil methyl ester & CNT & $50 \mathrm{ppm}$ \\
\hline & \multicolumn{4}{|c|}{ Engine performance: Higher BTE and lower BSFC } \\
\hline & \multicolumn{4}{|c|}{ Harmful emission: Lower $\mathrm{HC}$ emission. Higher $\mathrm{NO}_{x}$ emission } \\
\hline \multirow[t]{3}{*}{8} & Basha [141] & Jatropha methyl ester & CNT & $50 \mathrm{ppm}$ \\
\hline & \multicolumn{4}{|l|}{ Engine performance: Higher BTE } \\
\hline & \multicolumn{4}{|c|}{ Harmful emission: Harmful pollutants decreased } \\
\hline 9 & Hosseini et al. [142] & Waste cooking oil & CNT & 30,60 , and $90 \mathrm{ppm}$ \\
\hline & Engine performance: Increase in & wer (3.67\%), BTE (8.12\%), & d EGT $(5.57 \%)$ & \\
\hline & Harmful emission: $\mathrm{CO}, \mathrm{UHC}$, anc & ot exhaust emission reduce & with an increase in NO & ion \\
\hline 10 & El-Seesy et al. [143] & Jatropha methyl ester & GO & $25,50,75$, and $100 \mathrm{ppm}$ \\
\hline & Engine performance: BTE, peak & nder pressure, rate of press & e, and heat release rate & ced by $17,8,6$, and $6 \%$, respectively \\
\hline & $\begin{array}{l}\text { Harmful emission: } \mathrm{CO}, \mathrm{UHC} \text {, anc } \\
\text { results }\end{array}$ & x emissions decreases by & 50 , and $15 \%$, respecti & ppm dosing level produced better \\
\hline 11 & El-Seesy et al. [144] & Jatropha methyl ester & GNPS & $25,50,75$, and $100 \mathrm{ppm}$ \\
\hline & $\begin{array}{l}\text { Engine performance: Increased } \\
\text { rate increased by } 6,5 \text {, and } 5 \% \text {, }\end{array}$ & $\begin{array}{l}\text { TE }(25 \%) \text { and reduced in } \mathrm{BS} \\
\text { pectively. }\end{array}$ & C (20\%). Peak cylinder & re, rate of pressure, and heat release \\
\hline & $\begin{array}{l}\text { Harmful emission: A remarkable } \\
\text { produced better results. }\end{array}$ & ease in $\mathrm{CO}, \mathrm{UHC}$, and $\mathrm{NO}_{\mathrm{x}}$ & ssions by 60,50 , and 4 & pectively. The dosing level of $50 \mathrm{ppm}$ \\
\hline 12 & Hariram et al. [145] & Jojoba biodiesel & MWCNT & $50,100,1$ and $150 \mathrm{ppm}$ \\
\hline & Engine performance: Higher BTE & d lower BSFC & & \\
\hline & Harmful emission: Lower $\mathrm{CO}_{2}$ ar & moke emission. Higher $\mathrm{NC}$ & mission. The dosing le & $00 \mathrm{ppm}$ produced better results \\
\hline 13 & El-Seesy et al. [146] & Jojoba methyl ester & MWCNT & $10,20,30,40$, and $50 \mathrm{ppm}$. \\
\hline & Engine performance: Higher $p$ & ressure & & \\
\hline & ission: Lower $\mathrm{NO}_{\mathrm{x}}$, & and $\mathrm{CO}$ emissions. Th & & \\
\hline
\end{tabular}

Hariram et al. [145] added MWCNT nanoparticles into the Jojoba biodiesel and the addition of 50, 100, and $150 \mathrm{ppm}$ MWCNT nanoparticles reduced the ignition delay period. The BTE values of all concentration levels were found to be increased, while the BSFC reduced. The concentration level of $100 \mathrm{ppm}$ MWCNT nanoparticles produced better combustion characteristics and engine performance as well as low harmful emissions.

El-Seesy et al. [146] studied the effect of different concentrations of MWCNT (1-50 ppm) into the jojoba methyl ester diesel under different load conditions and engine speeds. The experimental analysis revealed that the addition of MWCNT nanoparticles improved the performance and emission characteristics. The BTE value increased upon the addition of MWCNT nanoparticle up to $16 \%$ in the biodiesel blend. At the same time, the BSFC performance decreased by $15 \%$. By adding the MWCNTs into the biodiesel blend, the emissions of $\mathrm{NO}_{\mathrm{x}}, \mathrm{UHC}$, and CO significantly reduced. With the nanoparticle's concentration of $20 \mathrm{ppm}$, the $\mathrm{NO}_{\mathrm{x}}$, CO, and UHC emissions 

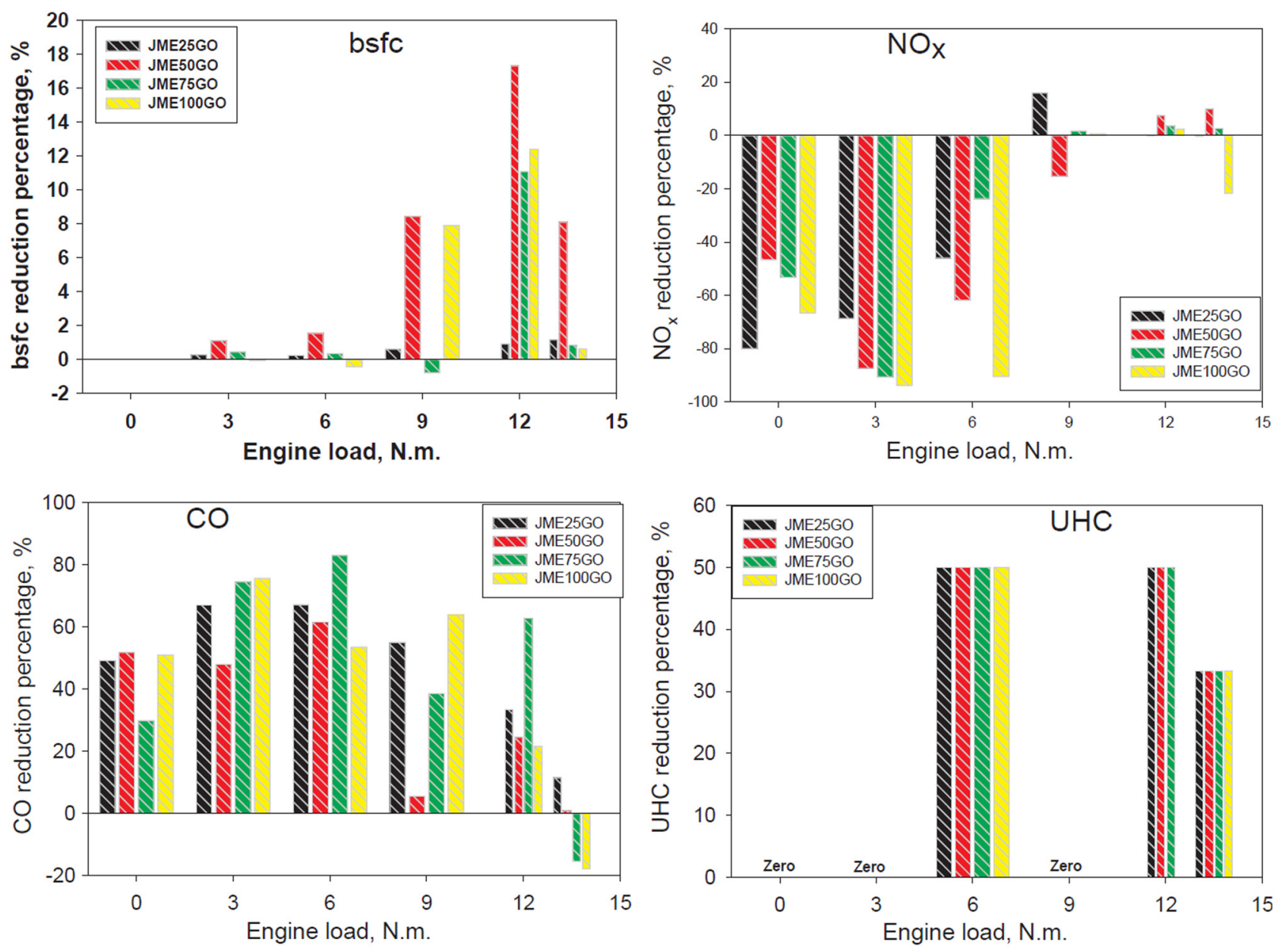

Figure 4: The reduction percentage of the $\mathrm{BSFC}, \mathrm{NO}_{\mathrm{x}}, \mathrm{CO}$, and $\mathrm{UHC}$ emissions under different engine loads [143].

decreased by $35 \%, 50 \%$, and $60 \%$, respectively Overall, the concentration level of $50 \mathrm{ppm}$ produced better combustion characteristics and engine performance as well as low harmful emissions.

\section{Conclusion}

In this article, a recent review of the effects of nanofluid as a fuel additive in diesel/biodiesel is presented. The application of nanofluid biodiesel blend in the ICE can serve as a potential approach in reducing GHG emissions and improving engine efficiency. Many previous studies demonstrated that nanoparticles can be used to enhance the fuel properties, engine performance, fuel combustion, and exhaust emission. Fuel properties are one of the most significant factors that determine the engine performance and combustion quality. The summary of this review article is listed as follows.
- The addition of nanoparticles plays a vital role in promoting better combustion quality. With the addition of nanoparticles to the diesel/biodiesel, it can improve the fuel properties such as kinematic viscosity, caloric value, flash point, density, and cetane number, leading to complete combustion. The increase in BTE is due to the catalytic activity and improvement in fuel properties. In contrast, a low calorific value will increase BSFC. In short, a higher calorific value will promote a lower BSFC and higher BTE.

- Fuel properties such as kinematic viscosity, caloric value, flash point, density, and cetane number also depend on the type of biodiesel, type of nanoparticle and its size, and the amount of dosing level. This may have a varied effect on the combustion and emission characteristics.

- Increasing the dosing level of nanoparticles can greatly enhance the engine performance and emission characteristics, excessive number of nanoparticles will lead 
to unburned fuel-air mixture during the combustion process.

- The addition of ethanol and nanoparticles in gasoline fuel can also improve engine performance and exhaust emissions.

- Among the above nanoparticles, aluminium is the best metal candidate, while CNT is used for non-metal nanoparticles. This is owing to their presence of excess oxygen quantity, and the positive effects of nanoparticles on the fuel properties (i.e. highest calorific value) of diesel/biodiesel blended could reportedly increase in combustion efficiency, leading to reduced BSFC and harmful emissions.

As a whole, the addition of nanoparticles in diesel/ biodiesel plays a significant role in improving the fuel properties and enhancing the performance of the $\mathrm{CI}$ engine as well as reducing the exhaust emissions.

\section{Current challenges and recommendations}

From authors' review, most of the results are favourable, because the addition of nanoparticles in the diesel/biodiesel can enhance the performance of $\mathrm{CI}$ engine and reduce the harmful emissions $\left(\mathrm{HC}, \mathrm{CO}\right.$, smoke, and $\mathrm{NO}_{\mathrm{x}}$ emissions) causing the global air pollution. This literature review reveals that most of the experiments conducted showed a remarkable improvement in producing a lower exhaust emission.

Moreover, there are contradictory observations by researchers regarding the engine performance such as BTE, BSFC, peak pressure, and emissions characteristics such as $\mathrm{HC}$, CO, smoke, and $\mathrm{NO}_{\mathrm{x}}$ emissions as noted in the literature. Among them, few researchers reported that $\mathrm{NO}_{\mathrm{x}}$ emission release was higher with the addition of additives. The discrepancy occurred due to the different types of biodiesel, types of nanoparticles and its size, and also its volume concentration. The particle size is one of the important key factors that affect the combustion quality. Further study is therefore needed to overcome this discrepancy by considering the source of vegetable oils and different types of nanoparticles and its size by varying the dosing level of nanoparticles.

Acknowledgements: The authors would like to express their appreciation to Universiti Teknologi Malaysia and the Ministry of Education for providing the financial support for this work through FRGS-MSRA research grant (Vote No: 5F273) and LRGS (Vote No: 4L891).

Conflict of interest: The authors declare no conflict of interest regarding the publication of this paper.

\section{References}

[1] Bhatti JS, Apps MJ, Lal R, Price MA. Anthropogenic changes and the global carbon cycle. Climate change managed ecosystems. Boca Raton, FL: CRC Press; 2006. p. 71-92.

[2] Trabalka JR, Reichle DE, editors. The changing carbon cycle: A global analysis. New York: Springer Sci Bus Media; 2013 Mar 9.

[3] IPCC. Climate change 2014: Synthesis report. Core Writing Team, Pachauri RK, Meyer LA, (eds.). Contribution of working groups I, II and III to the fifth assessment report of the intergovernmental panel on climate change. Geneva, Switzerland: IPCC; 2014.

[4] Uyumaz A. An experimental investigation into combustion and performance characteristics of an $\mathrm{HCCl}$ gasoline engine fueled with $n$-heptane, isopropanol and $n$-butanol fuel blends at different inlet air temperatures. Energ Convers Manage. 2015;98:199-207.

[5] He BQ, Liu MB, Zhao H. Comparison of combustion characteristics of $n$-butanol/ethanol-gasoline blends in a $\mathrm{HCCl}$ engine. Energ Convers Manage. 2015;95:101-9.

[6] Kahveci EE, Taymaz I. Experimental study on performance evaluation of PEM fuel cell by coating bipolar plate with materials having different contact angle. Fuel. 2019;253:1274-81.

[7] Taymaz I, Benli M. Emissions and fuel economy for a hybrid vehicle. Fuel. 2014;115:812-7.

[8] Yusof SN, Manap A, Afandi NM, Salim M, Misran H. Mechanical and wear properties of aluminum coating prepared by cold spraying. AIP conference proceedings (vol. 1669, no. 1, p. 020044). Melville, NY: AIP Publishing LLC; 2015 Jul 22.

[9] Ghassemieh E. Materials in automotive application, state of the art and prospects. New trends and developments in automotive industry. InTech. 2011;365-94.

[10] Davies J, Grant M, Venezia J, Aamidor J. Greenhouse gas emissions of the US transportation sector: Trends, uncertainties, and methodological improvements. Transp Res Rec. 2007;2017(1):41-6.

[11] Shaheen SA, Lipman TE. Reducing greenhouse emissions and fuel consumption: Sustainable approaches for surface transportation. IATSS Res. 2007;31(1):6-20.

[12] Yusof SN, Asako Y, Faghri M, Tan LK, bin Che Sidik NA. Numerical analysis for irreversible processes in a pistoncylinder system. Int J Heat Mass Transf. 2018;124:1097-106.

[13] Yusof SN, Asako Y, Ken TL, Sidik NA. Piston surface pressure of piston-cylinder system with finite piston speed. J Adv Res Fluid Mech Therm Sci. 2018;44(1):55-65.

[14] Yusof SN, Asako Y, Faghri M, Tan LK, bin Che Sidik NA, bin Aziz Japar WM. Numerical analysis of irreversible processes 
in a piston-cylinder system using LB1S turbulence model. Int J Heat Mass Transf. 2019;136:730-9.

[15] Giakoumis EG. A statistical investigation of biodiesel effects on regulated exhaust emissions during transient cycles. Appl Energ. 2012;98:273-91.

[16] Karim GA, Khan MO. Examination of effective rates of combustion heat release in a dual-fuel engine. J Mech Eng Sci. 1968;10(1):13-23.

[17] Kumar BR, Saravanan S. Effects of iso-butanol/diesel and $n$-pentanol/diesel blends on performance and emissions of a DI diesel engine under premixed LTC (low temperature combustion) mode. Fuel. 2016;170:49-59.

[18] Mwangi JK, Lee WJ, Chang YC, Chen CY, Wang LC. An overview: Energy saving and pollution reduction by using green fuel blends in diesel engines. Appl Energ. 2015;159:214-36.

[19] Jiaqiang E, Liu G, Zhang Z, Han D, Chen J, Wei K, et al. Effect analysis on cold starting performance enhancement of a diesel engine fueled with biodiesel fuel based on an improved thermodynamic model. Appl Energ.

2019;243:321-35.

[20] Jiaqiang E, Liu T, Yang W, Deng Y, Gong J. A skeletal mechanism modeling on soot emission characteristics for biodiesel surrogates with varying fatty acid methyl esters proportion. Appl Energ. 2016;181:322-31.

[21] Wu G, Lu Z, Xu X, Pan W, Wu W, Li J, et al. Numerical investigation of aeroacoustics damping performance of a Helmholtz resonator: Effects of geometry, grazing and bias flow. Aerosp Sci Technol. 2019;86:191-203.

[22] Pedrozo VB, May I, Guan W, Zhao H. High efficiency ethanoldiesel dual-fuel combustion: A comparison against conventional diesel combustion from low to full engine load. Fuel. 2018;230:440-51.

[23] Ghaffarzadeh S, Toosi AN, Hosseini V. An experimental study on low temperature combustion in a light duty engine fueled with diesel/CNG and biodiesel/CNG. Fuel. 2020;262:116495.

[24] Yesilyurt MK, Aydin M. Experimental investigation on the performance, combustion and exhaust emission characteristics of a compression-ignition engine fueled with cottonseed oil biodiesel/diethyl ether/diesel fuel blends. Energ Convers Manage. 2020;205:112355.

[25] Devarajan Y, Madhavan VR. Emission analysis on the influence of ferrofluid on rice bran biodiesel. J Chil Chem Soc. 2017;62(4):3703-7.

[26] Radhakrishnan S, Munuswamy DB, Devarajan $\mathrm{Y}$, Mahalingam A. Performance, emission and combustion study on neat biodiesel and water blends fuelled research diesel engine. Heat Mass Transf. 2019;55(4):1229-37.

[27] Saravanan S, Nagarajan G. Comparison of influencing factors of diesel with crude rice bran oil methyl ester in multi response optimization of NOx emission. Ain Shams Eng J. 2014;5(4):1241-8.

[28] Choi SU, Eastman JA. Enhancing thermal conductivity of fluids with nanoparticles, No. ANL/MSD/CP-84938; CONF951135-29. IL, USA: Argonne National Lab; 1995.

[29] Hong KS, Hong TK, Yang HS. Thermal conductivity of Fe nanofluids depending on the cluster size of nanoparticles. Appl Phys Lett. 2006;88(3):031901.

[30] Amrollahi A, Hamidi AA, Rashidi AM. The effects of temperature, volume fraction and vibration time on the thermo- physical properties of a carbon nanotube suspension (carbon nanofluid). Nanotechnol. 2008;19(31):315701.

[31] Ruan B, Jacobi AM. Ultrasonication effects on thermal and rheological properties of carbon nanotube suspensions. Nanoscale Res Lett. 2012;7(1):1-4.

[32] Chung SJ, Leonard JP, Nettleship I, Lee JK, Soong Y, Martello DV, et al. Characterization of $\mathrm{ZnO}$ nanoparticle suspension in water: Effectiveness of ultrasonic dispersion. Powder Technol. 2009;194(1-2):75-80.

[33] Hwang Y, Lee JK, Lee JK, Jeong YM, Cheong SI, Ahn YC, et al. Production and dispersion stability of nanoparticles in nanofluids. Powder Technol. 2008;186(2):145-53.

[34] Li X, Zhu D, Wang X. Evaluation on dispersion behavior of the aqueous copper nano-suspensions. J Colloid Interf Sci. 2007;310(2):456-63.

[35] Shanbedi M, Heris SZ, Maskooki A. Experimental investigation of stability and thermophysical properties of carbon nanotubes suspension in the presence of different surfactants. J Therm Anal Calorim. 2015;120(2):1193-201.

[36] Aalam CS, Saravanan CG. Effects of nano metal oxide blended Mahua biodiesel on CRDI diesel engine. Ain Shams Eng J. 2017;8(4):689-96.

[37] Nema VK, Singh A. Emission reduction in a dual blend biodiesel fuelled $\mathrm{Cl}$ engine using nano-fuel additives. Mater Today Proc. 2018;5(9):20754-9.

[38] Tang QY, Shafiq I, Chan YC, Wong NB, Cheung R. Study of the dispersion and electrical properties of carbon nanotubes treated by surfactants in dimethylacetamide. J Nanosci Nanotechol. 2010;10(8):4967-74.

[39] Li XF, Zhu DS, Wang XJ, Wang N, Gao JW, Li H. Thermal conductivity enhancement dependent $\mathrm{pH}$ and chemical surfactant for $\mathrm{Cu}-\mathrm{H}_{2} \mathrm{O}$ nanofluids. Thermochim Acta. 2008;469(1-2):98-103.

[40] Bandyopadhyaya R, Nativ-Roth E, Regev 0, YerushalmiRozen R. Stabilization of individual carbon nanotubes in aqueous solutions. Nano Lett. 2002;2(1):25-8.

[41] Xia G, Jiang $\mathrm{H}$, Liu R, Zhai Y. Effects of surfactant on the stability and thermal conductivity of $\mathrm{Al}_{2} \mathrm{O}_{3} /$ de-ionized water nanofluids. Int J Therm Sci. 2014;84:118-24.

[42] Sahooli M, Sabbaghi S, Shariaty Niassar M. Preparation of $\mathrm{CuO} /$ water nanofluids using polyvinylpyrolidone and a survey on its stability and thermal conductivity. Int J Nanosci Nanotechnol. 2012;8(1):27-34.

[43] Yu W, Xie H. A review on nanofluids: Preparation, stability mechanisms, and applications. J Nanomater. 2012;2012:435873.

[44] Chen L, Xie H, Li Y, Yu W. Nanofluids containing carbon nanotubes treated by mechanochemical reaction. Thermochim Acta. 2008;477(1-2):21-4.

[45] Chen L, Xie H. Properties of carbon nanotube nanofluids stabilized by cationic gemini surfactant. Thermochim Acta. 2010;506(1-2):62-6.

[46] Vedagiri P, Martin LJ, Varuvel EG, Subramanian T. Experimental study on NOx reduction in a grapeseed oil biodiesel-fueled $\mathrm{Cl}$ engine using nanoemulsions and SCR retrofitment. Env Sci Pollut Res. 2020;27:29703-18.

[47] Praveena V, Martin ML, Geo VE. Experimental characterization of $\mathrm{Cl}$ engine performance, combustion and emission parameters using various metal oxide nanoemulsion of 
grapeseed oil methyl ester. J Therm Anal Calorim. 2020;139(6):3441-56.

[48] Karthikeyan S, Elengo A, Prathima A. Performance, combustion and emission characteristics of a marine engine running on grape seed oil biodiesel blends with nano additive. Indian J Geo-Mar Sci. 2014;43:12.

[49] Chen AF, Adzmi MA, Adam A, Othman MF, Kamaruzzaman MK, Mrwan AG. Combustion characteristics, engine performances and emissions of a diesel engine using nanoparticle-diesel fuel blends with aluminium oxide, carbon nanotubes and silicon oxide. Energ Convers Manage. 2018;171:461-77.

[50] Gumus S, Ozcan H, Ozbey M, Topaloglu B. Aluminum oxide and copper oxide nanodiesel fuel properties and usage in a compression ignition engine. Fuel. 2016;163:80-7.

[51] Sahoo RR, Jain A. Experimental analysis of nanofuel additives with magnetic fuel conditioning for diesel engine performance and emissions. Fuel. 2019;236:365-72.

[52] D'Silva R, Binu KG, Bhat T. Performance and Emission characteristics of a $\mathrm{Cl}$ Engine fuelled with diesel and $\mathrm{TiO}_{2}$ nanoparticles as fuel additive. Mater Today Proc.

2015;2(4-5):3728-35.

[53] Devarajan Y, Munuswamy DB, Mahalingam A. Investigation on behavior of diesel engine performance, emission, and combustion characteristics using nano-additive in neat biodiesel. Heat Mass Transf. 2019;55(6):1641-50.

[54] Perumal V, Ilangkumaran $M$. The influence of copper oxide nano particle added pongamia methyl ester biodiesel on the performance, combustion and emission of a diesel engine. Fuel. 2018;232:791-802.

[55] Sajin JB, Pillai GO, Kesavapillai M, Varghese S. Effect of nanoparticle on emission and performance characteristics of biodiesel. Int J Ambient Energy. 2019;1-7.

[56] Lenin MA, Swaminathan MR, Kumaresan G. Performance and emission characteristics of a DI diesel engine with a nanofuel additive. Fuel. 2013;109:362-5.

[57] Tewari P, Doijode E, Banapurmath NR, Yaliwal VS. Experimental investigations on a diesel engine fuelled with multiwalled carbon nanotubes blended biodiesel fuels. Int J Emerg Technol Adv Eng. 2013;3(3):72-6.

[58] Narasiman, Jeyakumar, Mani. Experimental investigation of DI diesel engine performance with oxygenated additive and SOME biodiesel. J Therm Sci Technol. 2015;10(1):JTST0014.

[59] Sathiyamoorthi R, Puviyarasan M, Bhuvanesh BK, Joshua DB. Effect of $\mathrm{CeO}_{2}$ nano additive on performance and emission characteristics of diesel engine fuelled by neem oil-biodiesel. Int J Chem Sci. 2016;14:473-84.

[60] Gharehghani A, Asiaei S, Khalife E, Najafi B, Tabatabaei M. Simultaneous reduction of $\mathrm{CO}$ and NOx emissions as well as fuel consumption by using water and nano particles in diesel-biodiesel blend. J Clean Prod. 2019;210:1164-70.

[61] Annamalai M, Dhinesh B, Nanthagopal K, SivaramaKrishnan P, Lalvani Jl, Parthasarathy M, et al. An assessment on performance, combustion and emission behavior of a diesel engine powered by ceria nanoparticle blended emulsified biofuel. Energ Convers Manage. 2016;123:372-80.

[62] Nanthagopal K, Ashok B, Tamilarasu A, Johny A, Mohan A. Influence on the effect of zinc oxide and titanium dioxide nanoparticles as an additive with Calophyllum inophyllum methyl ester in a $\mathrm{Cl}$ engine. Energ Convers Manage. 2017;146:8-19.

[63] Anchupogu P, Rao LN, Banavathu B. Effect of alumina nano additives into biodiesel-diesel blends on the combustion performance and emission characteristics of a diesel engine with exhaust gas recirculation. Env Sci Pollut Res. 2018;25(23):23294-306.

[64] Nithya S, Manigandan S, Gunasekar P, Devipriya J, Saravanan WS. The effect of engine emission on canola biodiesel blends with $\mathrm{TiO}_{2}$. Int J Ambient Energy. 2019;40(8):838-41.

[65] Najafi G. Diesel engine combustion characteristics using nano-particles in biodiesel-diesel blends. Fuel. 2018;212:668-78.

[66] Miyamoto N, Hou Z, Harada A, Ogawa H, Murayama T. Characteristics of diesel soot suppression with soluble fuel additives. SAE Trans. 1987;96:792-8.

[67] Younis A, Chu D, Li S. Cerium oxide nanostructures and their applications. Funct Nanomater. 2016;53-68.

[68] Khalife E, Tabatabaei M, Najafi B, Mirsalim SM, Gharehghani A, Mohammadi P, et al. A novel emulsion fuel containing aqueous nano cerium oxide additive in dieselbiodiesel blends to improve diesel engines performance and reduce exhaust emissions: Part I - Experimental analysis. Fuel. 2017;207:741-50.

[69] Mei D, Li X, Wu Q, Sun P. Role of cerium oxide nanoparticles as diesel additives in combustion efficiency improvements and emission reduction. J Energy Eng.

2016;142(4):04015050.

[70] Sathiyamoorthi R, Sankaranarayanan G, Pitchandi K. Combined effect of nanoemulsion and EGR on combustion and emission characteristics of neat lemongrass oil (LGO)DEE-diesel blend fuelled diesel engine. Appl Therm Eng. 2017;112:1421-32.

[71] Sajith V, Sobhan CB, Peterson GP. Experimental investigations on the effects of cerium oxide nanoparticle fuel additives on biodiesel. Adv Mech Eng. 2010;2:581407.

[72] Pandey AK, Nandgaonkar M, Pandey U, Suresh S, Varghese A. The effect of cerium oxide nano particles fuel additive on performance and emission of karanja biodiesel fueled compression ignition military $585 \mathrm{~kW}$ heavy duty diesel engine. SAE Technical Paper; 2018.

[73] Pandey AK, Nandgaonkar M, Pandey U, Suresh S. Experimental investigation of the effect of karanja oil biodiesel with cerium oxide nano particle fuel additive on lubricating oil tribology and engine wear in a heavy duty 38.8 L, 780 HP Military CIDI Diesel Engine. SAE Technical Paper. 2018.

[74] Narendiranath BT, Praneeth VS. Effect of an additive in karanja biodiesel blends on the performance and emission characteristics of diesel engines. Int J Mech Eng Technol. 2018;9(4):837-46.

[75] Ananda Srinivasan C, Saravanan CG, Gopalakrishnan M. Emission reduction on ethanol-gasoline blend using cerium oxide nanoparticles as fuel additive. Part Sci Technol. 2018;36(5):628-35.

[76] Janakiraman S, Lakshmanan T, Chandran V, Subramani L. Comparative behavior of various nano additives in a DIESEL engine powered by novel Garcinia gummi-gutta biodiesel. J Clean Prod. 2020;245:118940. 
[77] Fu P, Bai X, Yi W, Li Z, Li Y, Wang L. Assessment on performance, combustion and emission characteristics of diesel engine fuelled with corn stalk pyrolysis bio-oil/diesel emulsions with $\mathrm{Ce}_{0} .7 \mathrm{Zr}_{0} .3 \mathrm{O}_{2}$ nanoadditive. Fuel Process Technol. 2017;167:474-83.

[78] Saraee HS, Jafarmadar S, Taghavifar H, Ashrafi SJ. Reduction of emissions and fuel consumption in a compression ignition engine using nanoparticles. Int J Environ Sci Technol. 2015;12(7):2245-52.

[79] Devendiran DK, Amirtham VA. A review on preparation, characterization, properties and applications of nanofluids. Renew Sust Energ Rev. 2016;60:21-40.

[80] Senthil Kumar J, Ramesh Bapu BR. Cerium oxide nano additive impact of VCR diesel engine characteristics by using Ginger grass oil blended with diesel. Int J Ambient Energy. 2019;1-6.

[81] Thangavelu SK, Arthanarisamy M. Experimental investigation on engine performance, emission, and combustion characteristics of a DI Cl engine using tyre pyrolysis oil and diesel blends doped with nanoparticles. Env Prog Sust Energy. 2020;39(2):e13321.

[82] Hawi M, Elwardany A, Ismail M, Ahmed M. Experimental investigation on performance of a compression ignition engine fueled with waste cooking oil biodiesel-diesel blend enhanced with iron-doped cerium oxide nanoparticles. Energies. 2019;12(5):798.

[83] Akram S, Mumtaz MW, Danish M, Mukhtar H, Irfan A, Raza SA, et al. Impact of cerium oxide and cerium composite oxide as nano additives on the gaseous exhaust emission profile of waste cooking oil based biodiesel at full engine load conditions. Renew Energ. 2019;143:898-905.

[84] Vairamuthu G, Sundarapandian S, Kailasanathan C, Thangagiri $B$. Experimental investigation on the effects of cerium oxide nanoparticle on Calophyllum inophyllum (Punnai) biodiesel blended with diesel fuel in DI diesel engine modified by nozzle geometry. J Energy Inst. 2016;89(4):668-82.

[85] Prabu A, Anand RB. Emission control strategy by adding alumina and cerium oxide nano particle in biodiesel. J Energy Inst. 2016;89(3):366-72.

[86] Selvan VA, Anand RB, Udayakumar M. Effect of cerium oxide nanoparticles and carbon nanotubes as fuel-borne additives in diesterol blends on the performance, combustion and emission characteristics of a variable compression ratio engine. Fuel. 2014;130:160-7.

[87] Nassir AK, Haroun AKS. Experimental study of effect of nanoparticles addition on combustion phasing in diesel engine. Int J Mech Mechatron Eng. 2018;18(1):87-97.

[88] Sathiamurthi P, Vinith KSK, Sivakumar A. Performance and emission test in $\mathrm{Cl}$ engine using magnetic fuel conditioning with nano additives. Int J Rec Technol Eng. 2019;8(3):7823-6.

[89] Venkatesan SP, Kadiresh PN. Influence of aluminum oxide nanoparticle additive on performance and exhaust emissions of diesel engine. Int J Appl Eng Res. 2015;10(3):5741-9.

[90] Basha JS. An experimental analysis of a diesel engine using alumina nanoparticles blended diesel fuel. SAE Technical Paper; 2014.
[91] Kao MJ, Ting CC, Lin BF, Tsung TT. Aqueous aluminum nanofluid combustion in diesel fuel. J Test Eval. 2008;36(2):186-90.

[92] Reddy BV, Maity SR, Pandey KM. Characterization of spray formed Al-alloys - A review. Rev Adv Mater Sci. 2019;58(1):147-58.

[93] Nayak SK, Pattanaik BP. Experimental investigation on performance and emission characteristics of a diesel engine fuelled with mahua biodiesel using additive. Energy Procedia. 2014;54:569-79.

[94] Raju VD, Kishore PS, Nanthagopal K, Ashok B. An experimental study on the effect of nanoparticles with novel tamarind seed methyl ester for diesel engine applications. Energ Convers Manage. 2018;164:655-66.

[95] Balasubramanian D, Venugopal IP, Viswanathan K. Characteristics investigation on Di diesel engine with nanoparticles as an additive in lemon grass oil. SAE Technical Paper; 2019.

[96] Soudagar ME, Nik-Ghazali NN, Kalam MA, Badruddin IA, Banapurmath NR, Ali MA, et al. An investigation on the influence of aluminium oxide nano-additive and honge oil methyl ester on engine performance, combustion and emission characteristics. Renew Energ. 2020;146:2291-307.

[97] Mahalingam S, Ganesan S. Effect of nano-fuel additive on performance and emission characteristics of the diesel engine using biodiesel blends with diesel fuel. Int J Ambient Energy. 2020;41(3):316-21.

[98] Shaafi T, Velraj R. Influence of alumina nanoparticles, ethanol and isopropanol blend as additive with dieselsoybean biodiesel blend fuel: Combustion, engine performance and emissions. Renew Energ. 2015;80:655-63.

[99] Ramesh DK, Kumar JD, Kumar SH, Namith V, Jambagi PB, Sharath S. Study on effects of alumina nanoparticles as additive with poultry litter biodiesel on performance, combustion and emission characteristic of diesel engine. Mater Today Proc. 2018;5(1):1114-20.

[100] Sivakumar M, Sundaram NS, Thasthagir MH. Effect of aluminium oxide nanoparticles blended pongamia methyl ester on performance, combustion and emission characteristics of diesel engine. Renew Energ. 2018;116:518-26.

[101] Aalam CS, Saravanan CG, Kannan M. Experimental investigations on a CRDI system assisted diesel engine fuelled with aluminium oxide nanoparticles blended biodiesel. Alex Eng J. 2015;54(3):351-8.

[102] Mehta RN, Chakraborty M, Parikh PA. Nanofuels: Combustion, engine performance and emissions. Fuel. 2014;120:91-7.

[103] Kumar AM, Kannan M, Nataraj G. A study on performance, emission and combustion characteristics of diesel engine powered by nano-emulsion of waste orange peel oil biodiesel. Renew Energ. 2020;146:1781-95.

[104] Typek J, Guskos N, Zolnierkiewicz G, Pilarska M, Guskos A, Kusiak-Nejman E, et al. Magnetic properties of $\mathrm{TiO}_{2} /$ graphitic carbon nanocomposites. Rev Adv Mater Sci. 2019;58(1):107-22.

[105] Yousefian R, Emadoddin E, Baharnezhad S. Manufacturing of the aluminum metal-matrix composite reinforced with microand nanoparticles of $\mathrm{TIO}_{2}$ through accumulative roll bonding process (ARB). Rev Adv Mater Sci. 2018;55(1):1. 
[106] Ichikawa S. Photoelectrocatalytic production of hydrogen from natural seawater under sunlight. Int J Hydrog Energ. 1997;22(7):675-8.

[107] Senthil Kumar J, Ramesh Bapu BR, Gugan R. Emission examination on nanoparticle blended diesel in constant speed diesel engine. Pet Sci Technol. 2020;38(2):98-105.

[108] Yuvarajan D, Babu MD, BeemKumar N, Kishore PA. Experimental investigation on the influence of titanium dioxide nanofluid on emission pattern of biodiesel in a diesel engine. Atmos Pollut Res. 2018;9(1):47-52.

[109] Karthikeyan P, Viswanath G. Effect of titanium oxide nanoparticles in tamanu biodiesel operated in a two cylinder diesel engine. Mater Today Proc. 2020;22:776-80.

[110] Praveen A, Rao GL, Balakrishna B. Performance and emission characteristics of a diesel engine using Calophyllum inophyllum biodiesel blends with $\mathrm{TiO}_{2}$ nanoadditives and EGR. Egyptian. J Pet. 2018;27(4):731-8.

[111] Balasubramanian D, Lawrence KR. Influence on the effect of titanium dioxide nanoparticles as an additive with Mimusops elengi methyl ester in a $\mathrm{Cl}$ engine. Env Sci Pollut Res. 2019;26(16):16493-502.

[112] El-Seesy Al, Hassan H, Dawood A, Attia AM, Kosaka H, Ookawara S. Investigation of the impact of adding titanium dioxide to jojoba biodiesel-diesel- $n$-hexane mixture on the performance and emission characteristics of a diesel engine. Internal combustion engine division fall technical conference (vol. 51982, p. V001T02A006). American Society of Mechanical Engineers; 2018 Nov 4.

[113] Balamurugan T, Nalini R. Experimental investigation on the effect of alkanes blending on performance, combustion and emission characteristics of four-stroke diesel engine. Int J Ambient Energy. 2016;37(2):192-200.

[114] Manigandan S, Gunasekar P, Devipriya J, Nithya S. Emission and injection characteristics of corn biodiesel blends in diesel engine. Fuel. 2019;235:723-35.

[115] Sundararajan NK, Ammal AR. Improvement studies on emission and combustion characteristics of $\mathrm{DICl}$ engine fuelled with colloidal emulsion of diesel distillate of plastic oil, $\mathrm{TiO}_{2}$ nanoparticles and water. Env Sci Pollut Res. 2018;25(12):11595-613.

[116] Örs I, Sarıkoç S, Atabani AE, Ünalan S, Akansu SO. The effects on performance, combustion and emission characteristics of $\mathrm{DICl}$ engine fuelled with $\mathrm{TiO}_{2}$ nanoparticles addition in diesel/biodiesel $/ n$-butanol blends. Fuel. 2018;234:177-88.

[117] Kandasamy A, Jabaraj DB. Performance and emission characteristics of $\mathrm{Cl}$ engine using biodiesel (cotton seed oil) blends with titanium oxide. J Veh Struct Syst. 2017;9(4):217-20.

[118] Pandian AK, Munuswamy DB, Radhakrishana S, Ramakrishnan RB, Nagappan B, Devarajan Y. Influence of an oxygenated additive on emission of an engine fueled with neat biodiesel. Pet Sci. 2017;14(4):791-7.

[119] Prabhu L, Kumar SS, Andrerson A, Rajan K. Investigation on performance and emission analysis of $\mathrm{TIO}_{2}$ nanoparticle as an additive for bio-diesel blends. J Chem Pharm Sci Spec. 2015;7:408-12.

[120] Mehregan M, Moghiman M. Experimental investigation of the distinct effects of nanoparticles addition and urea-SCR after- treatment system on NOx emissions in a blended-biodiesel fueled internal combustion engine. Fuel. 2020;262:116609.

[121] Vedagiri P, Martin LJ, Varuvel EG. Characterization study on performance, combustion and emission of nano additive blends of grapeseed oil methyl ester fuelled $\mathrm{Cl}$ engine with various piston bowl geometries. Heat Mass Transf. 2020;56(3):715-26.

[122] Amirabedia M, Jafarmadar S, Khalilarya S, Kheyrollahi J. Experimental comparison the effect of $\mathrm{Mn}_{2} \mathrm{O}_{3}$ and $\mathrm{CO}_{3} \mathrm{O}_{4}$ nano additives on the performance and emission of $\mathrm{SI}$ gasoline fueled with mixture of ethanol and gasoline. Int J Eng. 2019;32(5):769-76.

[123] Amirabedi M, Jafarmadar S, Khalilarya S. Experimental investigation the effect of $\mathrm{Mn}_{2} \mathrm{O}_{3}$ nanoparticle on the performance and emission of SI gasoline fueled with mixture of ethanol and gasoline. Appl Therm Eng. 2019;149:512-9.

[124] Tamilvanan A, Balamurugan K, Vijayakumar M. Effects of nano-copper additive on performance, combustion and emission characteristics of Calophyllum inophyllum biodiesel in $\mathrm{Cl}$ engine. J Therm Anal Calorim. 2019;136(1):317-30.

[125] Venu H, Appavu P. Experimental studies on the influence of zirconium nanoparticle on biodiesel-diesel fuel blend in $\mathrm{Cl}$ engine. Int J Ambient Energy. 2019;1-7.

[126] Yogaraj D, Mohamed Iqbal S, Gokulakrishna R, Meikandan M. Performance test and emission characteristics of diesel engine with alternate fuel blends and nano additives. Int J Ambient Energy. 2019;1-5.

[127] Kalaimurugan K, Karthikeyan S, Periyasamy M, Mahendran G, Dharmaprabhakaran T. Experimental studies on the influence of copper oxide nanoparticle on biodieseldiesel fuel blend in $\mathrm{Cl}$ engine. Energ Source Part A Recov Util Environ Effects. 2019;1-6.

[128] Kalaimurugan K, Karthikeyan S, Periyasamy $M$, Mahendran G, Dharmaprabhakaran T. Performance, emission and combustion characteristics of $\mathrm{RuO}_{2}$ nanoparticles addition with neochloris oleoabundans algae biodiesel on $\mathrm{Cl}$ engine. Energ Source Part A Recov Util Environ Effects. 2019;1-15.

[129] Srinidhi C, Madhusudhan A, Channapattana SV. Effect of NiO nanoparticles on performance and emission characteristics at various injection timings using biodiesel-diesel blends. Fuel. 2019;235:185-93.

[130] Prabakaran B, Vijayabalan P. Influence of zinc oxide nano particles on performance, combustion and emission characteristics of butanol-diesel-ethanol blends in $\mathrm{DI} \mathrm{Cl}$ engine influence of zinc oxide nano particles on performance, combustion and emission characteristics of butanol-die. IOP Conf Series Mater Sci Eng (vol. 377, p. 012069); 2018 Jun.

[131] Prabakaran B, Udhoji A. Experimental investigation into effects of addition of zinc oxide on performance, combustion and emission characteristics of diesel-biodiesel-ethanol blends in $\mathrm{Cl}$ engine. Alex Eng J. 2016;55(4):3355-62.

[132] Gangwar A, Bhardawaj A, Singh R, Kumar N. Enhancement in performance and emission characteristics of diesel engine by adding alloy nanoparticle. SAE Technical Paper; 2016 Oct 17.

[133] Zhang X, Zhang Y, Tian B, Song K, Liu P, Jia Y, et al. Review of nano-phase effects in high strength and conductivity copper alloys. Nanotechnol Rev. 2019;8(1):383-95. 
[134] Soudagar ME, Nik-Ghazali NN, Kalam MA, Badruddin IA, Banapurmath NR, Khan TY, et al. The effects of graphene oxide nanoparticle additive stably dispersed in dairy scum oil biodiesel-diesel fuel blend on $\mathrm{Cl}$ engine: Performance, emission and combustion characteristics. Fuel. 2019;257:116015.

[135] Mei D, Zuo L, Adu-Mensah D, Li X, Yuan Y. Combustion characteristics and emissions of a common rail diesel engine using nanoparticle-diesel blends with carbon nanotube and molybdenum trioxide. Appl Therm Eng. 2019;162:114238.

[136] Hosseinzadeh-Bandbafha H, Khalife E, Tabatabaei M, Aghbashlo M, Khanali M, Mohammadi P, et al. Effects of aqueous carbon nanoparticles as a novel nanoadditive in water-emulsified diesel/biodiesel blends on performance and emissions parameters of a diesel engine. Energ Convers Manage. 2019;196:1153-66.

[137] Sivathanu N, Valai Anantham N. Impact of multi-walled carbon nanotubes with waste fishing net oil on performance, emission and combustion characteristics of a diesel engine. Env Technol. 2019;1-2.

[138] Sulochana G, Bhatti SK. Performance, emission and combustion characteristics of a twin cylinder 4 stroke diesel engine using nano-tubes blended waste fry oil methyl ester. Mater Today Proc. 2019;18:75-84.

[139] El-Seesy Al, Hassan H. Investigation of the effect of adding graphene oxide, graphene nanoplatelet, and multiwalled carbon nanotube additives with $n$-butanol-Jatropha methyl ester on a diesel engine performance. Renew Energ. 2019;132:558-74.

[140] Sandeep K, Rajashekhar CR, Karthik SR. Experimental studies on effect of nano particle blended biodiesel combustion on performance and emission of $\mathrm{Cl}$ engine. MS\&E. 2018;376(1):012019.
[141] Basha JS. Impact of carbon nanotubes and Di-ethyl ether as additives with biodiesel emulsion fuels in a diesel engine - An experimental investigation. J Energy Inst. 2018;91(2):289-303.

[142] Hosseini SH, Taghizadeh-Alisaraei A, Ghobadian B, Abbaszadeh-Mayvan A. Performance and emission characteristics of a $\mathrm{Cl}$ engine fuelled with carbon nanotubes and diesel-biodiesel blends. Renew Energ. 2017;111:201-13.

[143] EL-Seesy Al, Hassan H, Ookawara SJ. Performance, combustion, and emission characteristics of a diesel engine fueled with Jatropha methyl ester and graphene oxide additives. Energ Convers Manage. 2018;166:674-86.

[144] El-Seesy Al, Hassan H, Ookawara S. Effects of graphene nanoplatelet addition to jatropha biodiesel-diesel mixture on the performance and emission characteristics of a diesel engine. Energy. 2018;147:1129-52.

[145] Hariram V, Udhayakumar V, Karthick P, Andrews A, Arunraja A, Seralathan S, et al. Effect of carbon nanotubes on oxygenated jojoba biodiesel-diesel blends in direct injection $\mathrm{Cl}$ engines. Int J Veh Struct Syst. 2018;10:6.

[146] El-Seesy Al, Abdel-Rahman AK, Bady M, Ookawara SJ. Performance, combustion, and emission characteristics of a diesel engine fueled by biodiesel-diesel mixtures with multiwalled carbon nanotubes additives. Energ Convers Manage. 2017;135:373-9.

[147] Guo K, Miao H, Liu L, Zhou J, Liu M. Effect of graphene oxide on chloride penetration resistance of recycled concrete. Nanotechnol Rev. 2019;8(1):681-9.

[148] Power AC, Gorey B, Chandra S, Chapman J. Carbon nanomaterials and their application to electrochemical sensors: A review. Nanotechnol Rev. 2018;7(1):19-41. 